\title{
THE MONTANA EARTHQUAKE OF JUNE 27, 1925
}

\author{
By J. T. PARDeE
}

\section{SUMMARY}

The earthquake of June 27, 1925, in Montana caused considerable damage within an area of 600 square miles or more, the center of which is in latitude $46^{\circ} 5^{\prime} \mathrm{N}$. and longitude $111^{\circ}$ $20^{\prime}$ W., a short distance southeast of Lombard. It was a seismic disturbance of the first order of magnitude, but, owing to the hour at which it occurred and to other fortunate circumstances, no lives were lost and no fires broke out. The shock was startling throughout an area extending 75 miles or more in all directions from the epicenter and was sensible to persons within an area of 310,000 square miles. Within the epicentral area brick buildings suffered severely, rocks fell from cliffs, cracks opened in the ground, and the inhabitants experienced the usual symptoms of illness and emotions of alarm. Isoseismals drawn according to the Rossi-Forel scale show a wide indentation at the south due to a rapid decline of intensity in the 'volcanic area of Snake River Plain and Yellowstone Park.

The main shock was preceded by two light foreshocks and followed by a great many aftershocks, one of which, occurring about three-quarters of an hour later, was almost as severe as the main shock.

The epicenter is in Clarkston Valley, a lowland surrounded by mountains of severely folded Mesozoic and older rocks and floored with Tertiary "lake beds" and Recent alluvium. Physiographic evidence indicates that Clarkston Valley is a structural depression bounded on the east by a fault of post-Miocene age. Presumably the origin of the earthquake was on this fault at a considerable depth below the surface. It is concluded that the region is in a state of moderate seismic activity and is likely in the future to be visited by an occasional severe shock.

\section{INTRODUCTION}

On June 27, 1925, practically all of Montana and parts of the neighboring States and Provinces were shaken by an earthquake of marked intensity. The shock, which was immediately preceded by a light foreshock, came at approximately 6.21 p. m., mountain time. Newspaper reports published the following days indicated that the greatest damage occurred in the villages of Three Forks, Logan, and Manhattan and at Deer Park, where a large rock slide blocked the Chicago, Milwaukee \& St. Paul Railway. The area thus indicated lies from 20 to 40 miles northwest of Bozeman and about 55 miles east of Butte and an equal distance southeast of Helena. The epicenter as subsequently determined is a short distance southeast of Lombard, at approximately $46^{\circ} 5^{\prime}$ north latitude and $111^{\circ} 20^{\prime}$ west longitude. Three Forks contains about 1,200 inhabitants, Manhattan 600, and Logan 300. The remainder of the area of high intensity is very thinly inhabited.
The effects of the earthquake were investigated by the writer within the periods of July 10 to 31 and August 29 to September 5, 1925. Most of the settlements within a radius of 50 miles of the epicenter were visited, and trips were made to a few more distant points. The work consisted mainly in observing the remaining visible effects upon structures and natural objects and obtaining first-hand records from individual observers. In addition the geologic features of the epicentral area were briefly examined. (See pls. 3 and 4.)

For valuable information the writer is indebted to the many persons interviewed, and in particular to W. T. Lathrop, of the United States Weather Bureau at Helena; J. P. Swarts, W. P. Luburg, and H. P. Allen, Northern Pacific Railway operators at Lombard; and A. D. Burkett, chemist of the Three Forks Portland Cement Co. at Trident.

\section{EFFECTS OF THE EARTHQUAKE}

\section{DAMAGE TO BUILDINGS}

The greatest damage caused by the earthquake was shown by the school buildings at Manhattan, Logan, and Three Forks and a church at Three Forks (pls. 5 and 6), all of which were built of brick. The church is almost a complete wreck. The schoolhouses, though very seriously damaged, were not beyond repair. In the business sections of Three Forks and Manhattan most brick, stone, and cement-block buildings were seriously damaged, but none were completely wrecked. Some brick and cement houses and virtually all frame buildings escaped serious injury. Rather serious damage was done to brick schoolhouses at Willow Creek, Bozeman, Radersburg, and White Sulphur Springs, to the courthouse and jail at White Sulphur Springs (pl. 6, $B$ ), and to cement walls and cement block buildings at Trident. Damages to five schoolhouses in Gallatin County (two at Manhattan and one each at Three Forks, Logan, and Willow Creek) were estimated by the State architect at approximately $\$ 62,000$. The additional property loss in the towns mentioned probably is not large. There was also damage at many other places within a radius of 75 miles of the epicenter. This damage consisted mostly of breaks in chimneys, plaster, and plate-glass windows 
In addition many persons suffered losses by reason of merchandise and household effects being thrown about and broken. No estimates of the amounts of these losses are available.

From even a casual inspection it is apparent that all well-constructed buildings of whatever type escaped with little damage. Buildings faced or veneered with brick laid up without being tied or bonded to the inner walls suffered the most. The schoolhouses (pls. 5 and 6) are conspicuous examples. In Three Forks several walls made of common brick tied in the usual way with a layer of "headers" every fifth or sixth row were observed to be practically undamaged, though they adjoined veneered or faced walls that had failed. Some walls tied as described were wrecked, but their failure was due to poor mortar, as shown by the fact that the fallen bricks were generally separated from one another. At White Sulphur Springs part of the cornice and veneer on the one-story brick jail was sheared from the inner wall, owing to the lack of ties or bonding (pl. $6, B$ ). In the same town the peaks of the walls forming the gable ends of a two-story brick school and the two-story stone courthouse fell. The school had previously been condemned as unsafe, but the courthouse, though old, was apparently a substantial building. The gable peaks probably fell because they lacked the support of adjoining walls. At Radersburg the brick veneer on the one-story schoolhouse was partly sheared off.

\section{DAMAGE TO RAILROADS}

At the west portal of tunnel No. 8, near Deer Park, on the Chicago, Milwaukee \& St. Paul Railway, the earthquake caused a rock slide, estimated at 40,000 cubic yards, that not only blocked the track but obstructed the canyon of Sixteenmile Creek, causing a lake to form (pl. 7, B). Two weeks was required to build a temporary trac- cound the slide, so that the railroad could resume traffic over this part of its line. Clearing the permanent track would, it was estimated, take several months. A report current in newspapers soon after the earthquake that the tunnel at Deer Park had been destroyed was erroneous. It had been clogged by débris at one portal but otherwise was undamaged. Between Deer Park and Lombard rocks fell on the track at several places, without, however, causing serious damage. At Cardinal a water tank of an older type, supported by timbers, was thrown down. At several places near Lombard the Northern Pacific Railway track was broken or obstructed by masses of fallen rock (pl. 8).

\section{DAMAGE BY FIRE}

Fortunately, no fires were caused by the earthquake, but an indirect result of it was a fire the night of July 20 which destroyed the main business block in Toston. This fire caught from a chimney that had been cracked by the earthquake and was not yet repaired. Efforts to put out the fire were hindered by a lack of water, due also to the earthquake, which had cut off the public supply formerly derived from gravel beneath the dry channel of Sixmile Creek.

\section{INJURY TO PERSONS}

Though many persons experienced narrow escapes in the Montana earthquake, none lost their lives, and only two were reported to have been injured. This fortunate lack of casualties is no doubt due to the fact that the shock came at a time when schools, churches, and other places of public assembly were vacant. The people were mostly on the streets or in their homes and away from the larger buildings that collapsed. At Three Forks a woman had a leg broken as a result of falling or being thrown down by the shock, and near Ennis a man received slight injuries when the vibrations sheared the automobile in which he was riding off of the road. A west-bound Chicago, Milwaukee \& St. Paul Railway passenger train in two sections and a Northern Pacific Railway local passenger train were in the epicentral area near Lombard when the shock came. The Chicago, Milwaukee \& St. Paul train sections had only a few minutes before passed the place where the Deer Park slide buried the track.' They came to a stop while huge rocks were falling on the tracks in front of them and behind them, and their escape without a scratch seems little short of miraculous.

\section{EMOTIONS, SENSATIONS, ETC.}

The earthquake was violent enough to alarm the inhabitants generally throughout an area having a radius of as much as 75 miles from the epicenter. In Three Forks and other places near the epicenter many persons became wildly excited or hysterical, and the alarm caused by the main shock was renewed and increased by several of the closely following aftershocks. Because of earth motion during the heaviest parts of the main shock and of the first aftershock many persons were unable to walk or go toward a door or in any other certain direction. Near Three Forks a man who had raised his foot to step over a ditch was unable to change this pose for a few seconds; then he fell into the ditch: Persons sitting were unable to rise out of their chairs. A man who was in one of the damaged schoolhouses at Manhattan probably owes his life to the fact that he was unable to get to the door for a few seconds, during which several heavy masses of brick fell just outside. Many persons were partly or completely thrown down and in falling caught at the nearest object for support. A lady thus thrown in the street at Three Forks found herself clasping the knees of a strange man.

As soon as persons were able to regain their feet or make progress despite the earth movements they lost 


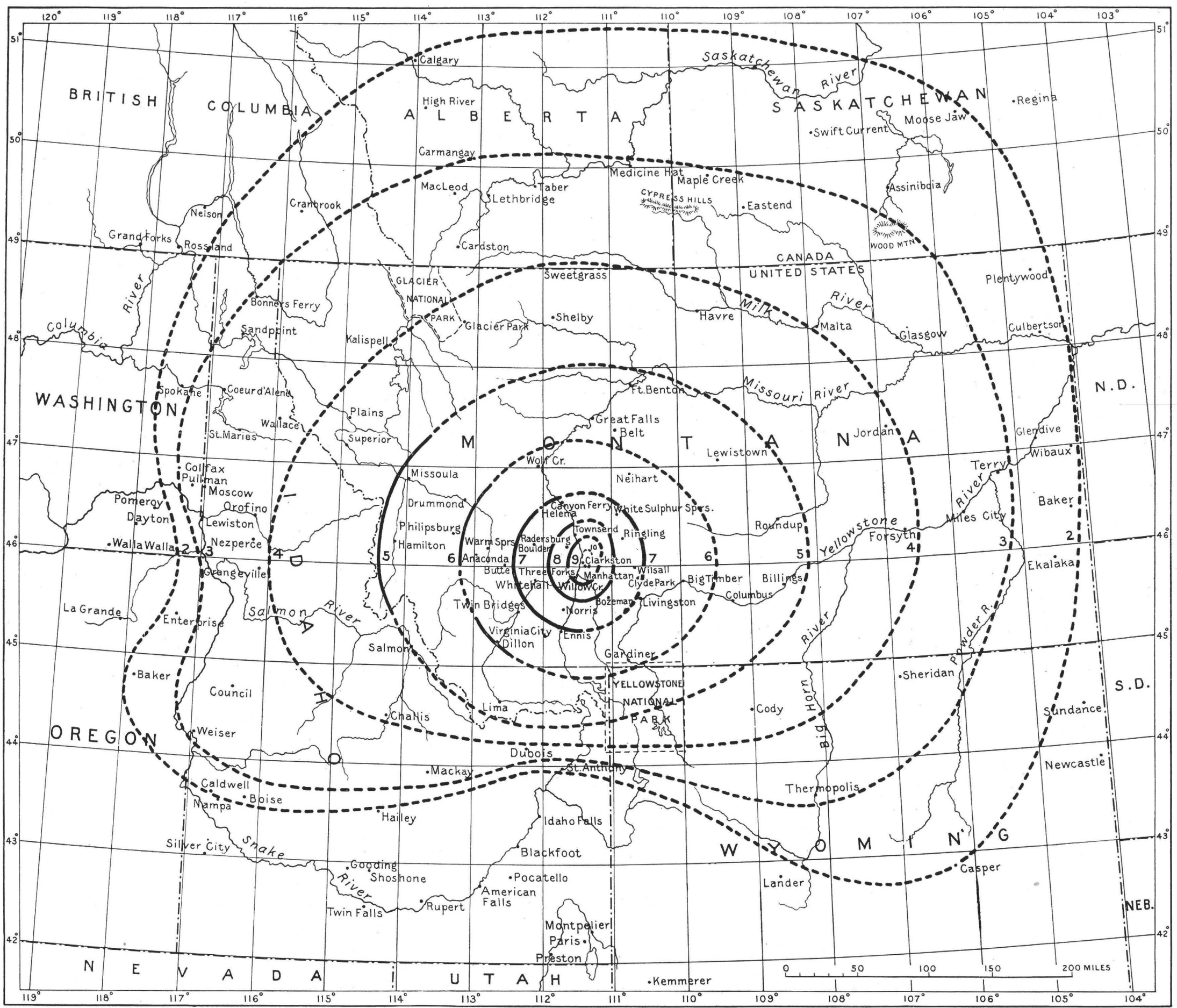

ISOSEISMAL LINES FOR MONTANA EARTHQUAKE OF JUNE 27, 1925 


.



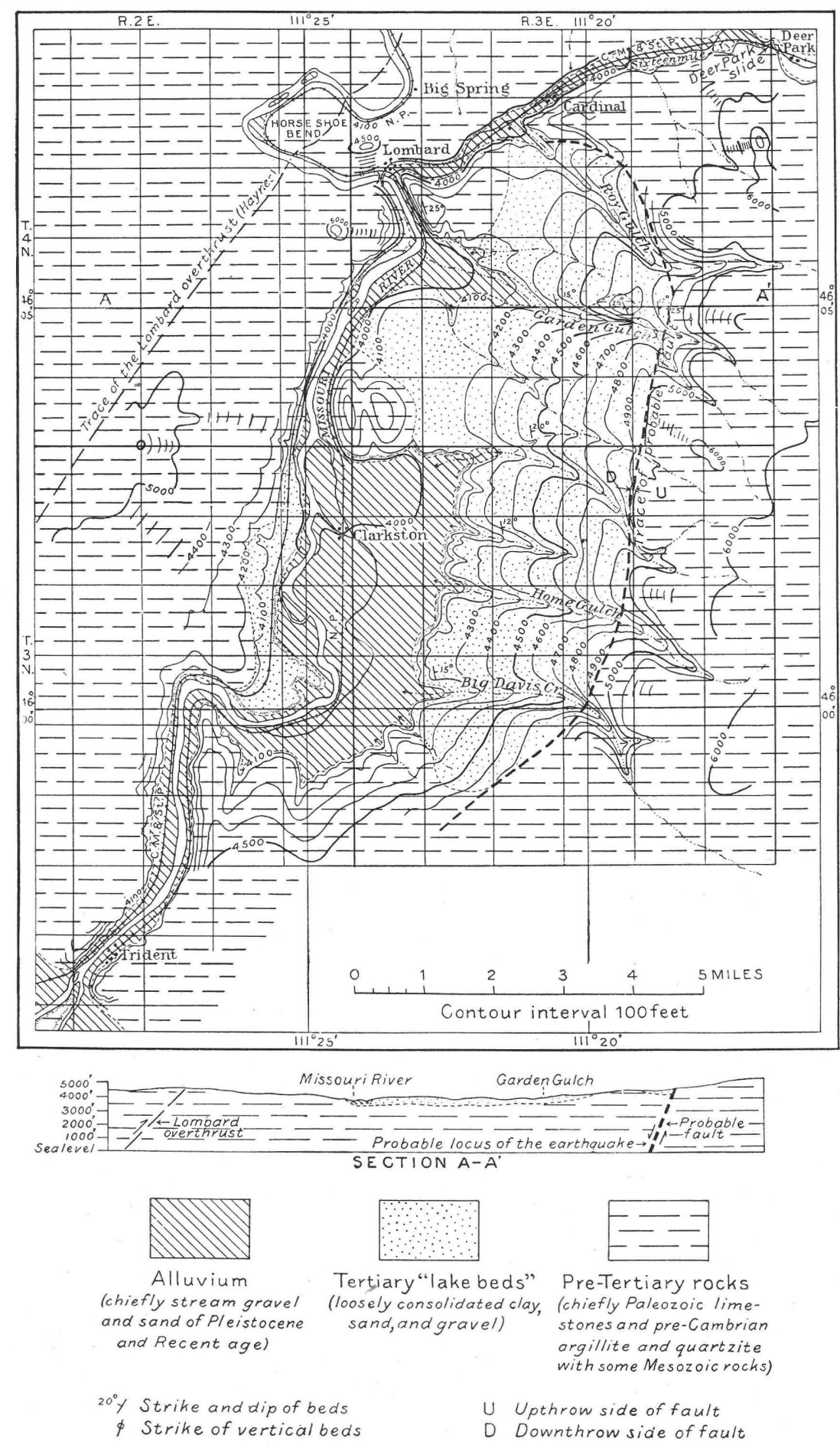

GEOLOGY OF THE EPICENTRAL AREA FOR MONTANA EARTHQUAKE OF JUNE 27, 1925 

no time in getting out of doors. In their excitement some persons picked up articles of no value. At Butte a woman is said to have laid down her baby and picked up the cat. Within a large area nearly everyone experienced more or less dizziness or nausea, and many felt a nervousness difficult to overcome for days or weeks afterward.

Most persons who had not already eaten failed to get their suppers that night. Near the epicenter many tables with suppers already served were thrown to the floor in a general mixup with other household articles. At Three Forks and places similarly situated dishes were commonly upset, and in general the people became too excited or ill to think of eating. Many of the inhabitants of Three Forks, Manhattan, and other places and even a few as far away as Butte and Anaconda remained out of doors part or all of the night after the earthquake. At Three Forks and other places that suffered conspicuous damage to buildings the people wisely did their cooking out of doors for several days or until their chimneys could be repaired. Fortunately, because it was summer, this caused the least amount of inconvenience, and for the same reason the houses did not need to be warmed. There is record of only one fire resulting from the use of a damaged chimney (p. 8).

Fright or terror was exhibited also by domestic animals within the area of startling shock, but few details were obtained on this phase of the subject.

\section{EFFECT UPON MINES}

Contrary to a rather widespread apprehension, the workings of mines were not damaged by the earthquake, and in fact the shock was not generally noticed by the miners who were underground at the time. At Barker a group of miners who were at work in a stope at a depth of 250 feet did not feel the shock, though it was generally noticed in that neighborhood by persons at the surface. So far as learned the thousands of miners at Butte who were underground at the time were generally unaware that an earthquake had occurred. In view of the fact that mine workings are generally constructed so as to withstand the jars from blasting, it is not surprising that they would resist damage by the less violent vibrations of this earthquake. Owing to the common occurrence of the jars caused by blasting, miners at work would not be likely to notice especially the somewhat similar vibrations of seismic origin. Furthermore, as these vibrations are less destructive in areas of solid rock than in loose materials, they would be less noticeable underground than at the surface.

\section{ROCK SLIDES}

Rocks and rock masses were shaken down rather generally from the steep slopes and cliffs existing within a radius of 12 or 15 miles of the epicenter, and a few rock falls occurred as far away as 40 miles.
Deer Park slide.-The largest mass dislodged by the earthquake was that which blocked the valley of Sixteenmile Creek at the west portal of tunnel No. 8, near Deer Park (pl. 7, $A$ ). The size of this slide does not mean, however, that the shaking was more severe in that locality than elsewhere, but that at that point an unusually large mass was already sufficiently loosened by erosion to be easily shaken down. Tunnel No. 8 goes through a narrow limestone spur that projects a short distance from the south wall of the canyon and causes Sixteenmile Creek to make a north bend (pl. 4). At the point of the spur the canyon is narrow, and its floor is practically occupied by the stream, which is 10 to 12 yards wide. Above and below the spur the canyon widens a few hundred feet. The east side of the spur, which faces upstream, is a sheer wall of limestone (pl. 7, B), which before the slide was 100 to 300 feet high. The north side of the canyon opposite the spur is a similar wall, and the west or downstream side of the spur is only a little less precipitous. Surmounting the walls on both sides of the canyon are steep slopes that rise 1,000 feet higher. The gorgelike constriction of the valley at this place is due to a belt of resistant Paleozoic limestone that trends northward across the course of the stream. The bend in the gorge is probably an incised meander. The limestone dips about $30^{\circ} \mathrm{W}$. and therefore inclines downstream and at right angles to the axis of the spur. A fault or slip plane. that coincides nearly with the bedding (pl. 9) touches the top of tunnel No. 8 at or near its west portal. Its trace appears about 60 feet above the tunnel at the east portal, in the vertical east wall of the spur (pl. $7, B$ ). This trace is visible farther south and also across the stream on the north side of the canyon (pl. 10, A), where it shows the maximum dip. Above and below this fracture are other similar slip planes. All of them probably were caused by the readjustments between the beds necessitated by the folding, and none are to be regarded as major structural features.

The mass of the spur above the fault plane described fell during the earthquake. Prior to that event its supports had been cut away on all sides except the south. The shaking, therefore, easily broke it loose along joints and minor fractures and started it sliding down the inclined floor on which it lay. Scratches made on this plane by the sliding mass go across small grooves and ridges made during previous fault movements.

Stides near Lombard.-For a mile or more north and south of Lombard, Missouri River is bordered on the east side by limestone cliffs and talus slopes several hundred feet high (pl. 10, B), at the foot of which the Northern Pacific Railway is built. On the west side of the river are lower cliffs beneath which the Chicago, Milwaukee \& St. Paul Railway passes for a short distance. Fortunately, the bedding planes in 
the cliffs east of the river are nearly horizontal. If their dip was toward the river slides probably exceeding that near Deer Park would have occurred. Joint planes were opened in these rocks, however (pl. 11, $A$ ), and considerable material was shaken down (pl. $8, B$ ). Solid masses weighing as much as 100 tons were detached from the cliffs and rolling down smashed the track (pl. 8, A). One of these masses estimated to weigh 30 tons is illustrated on Plate $11, B$. Along Sixteenmile Creek below the Deer Park slide and along Missouri River west of Lombard the Chicago, Milwaukee \& St. Paul track was similarly obstructed in many places. In all tributary canyons or other places near by where steep or cliff-like slopes occur much material was dislodged and added to the talus accumulations already existing. Observers along Sixteenmile Creek reported that for some time after the rocks began to fall the air was filled with a dense and choking dust. At Lombard the cliffs were hidden for several minutes by a cloud of dust, below which the rock débris could be seen rolling and sliding down to the river.

Rock falls in outlying areas.-Beyond the epicentral area rock falls of comparatively small extent occurred along the bluffs adjacent to Madison River south of Three Forks, along Jefferson River above Willow Creek, near Accola, and near Canyon Ferry. Most of these were masses that were well on the way to being let down by the ordinary processes of erosion. Dust arising from some rock falls near. Willow Creek appeared from a distance like smoke and led to the report that the town was on fire.

\section{GROUND CRACKS}

Newly formed ground cracks were observed in many places within a radius of 15 or 20 miles of the epicenter and also at one place, Canyon Ferry, about 40 miles distant. Apparently all were due to the shaking, and none represented a surface slip along the line of a deepseated fault. Those described in the following paragraphs were observed in or near the epicentral area.

Roy Gulch.-Cracks on both sides of Roy Gulch, a short distance southeast of Cardinal, extend for a quarter of a mile or more in a southeasterly direction parallel to the gulch and bound an area of alluvium that in places has settled 2 feet or more. At the top of the slope southwest of the gulch is a series of more or less continuous cracks extending also in a southeasterly direction for a mile or more. These cracks are branching, and at one place they occupy a zone several feet wide in which the ground is completely shattered and broken into clods that have been shuffled about and overturned (pl. 12, A). The cracks appear to extend through the soil and into the underlying Tertiary "lake beds," which here consist of moderately hardened layers of clay and sand.
Garden Gulch.-In the bottom of Garden Gulch, about 3 miles south of Cardinal, several cracks were observed in alluvium, causing certain areas to settle and thus obstruct the flow of water through ditches. At another place three cracks having a direction a little west of south cut across a ridge of Tertiary "lake beds." These cracks are each 100 yards or more long and from 1 to 3 or 4 inches wide. The ground on the west side of each had settled slightly.

North of Cardinal.-Near the ranches of Jonas Stockburger and Dave Johnson, respectively about 2 miles northeast and 3 miles north of Cardinal, many ground cracks were observed that range from 50 to 200 or 300 feet in length and from 1 to 3 inches in width. These occur in a hilly region composed chiefly of Paleozoic limestones bearing a rather thin soil or surface mantle. The cracks appear in the soil and generally follow along the foot of a hill just below the outcrops of bare rock. Whether or not they penetrate the rock beneath the soil is not shown. As a rule the area on the lower side of each crack has settled a little.

Near Three Forks.-On the highway northeast of Three Forks a crack several rods long and several inches wide opened in the embankment forming the approach to the bridge over Jefferson River. The crack had been filled up and was not visible when the writer visited the scene, but evidence of it is given by a photograph (pl. 12, B). A report published in the papers soon after the earthquake stating that a fissure had opened extending continuously from Three Forks to Manhattan was apparently without foundation.

Greyson Creek.-At John Denzer's place, about 15 miles north of Cardinal, on alluvial land bordering Greyson Creek, a crack opened more than 100 yards long and 6 inches in maximum width. It is parallel to the creek, and the bank on that side has settled a little.

Canyon Ferry.-In the field of William Ames, near Canyon Ferry, cracks 2 or 3 inches in maximum width (pl. 13, A) partly surround an area of an acre or less that has settled slightly. This block lies in an area of alluvium in the valley near the edge of the bench lands. It includes a shallow swale that is not crossed by a stream, the swale apparently being the result of settling at some former time.

\section{CHANGES IN SPRINGS AND WELLS}

Many springs within a radius of 50 miles from the epicenter were increased or diminished by the earthquake. Some were made turbid for a short time. Several wells went dry, and others became muddy. The ground-water flow beneath the dry bed of Sixmile Creek, upon which the town of Toston depended mainly for its public water supply, ${ }^{1}$ failed shortly after

\footnotetext{
1 U. S. Geol. Survey Water-Supply Paper 539, p. 52, 1925.
} 


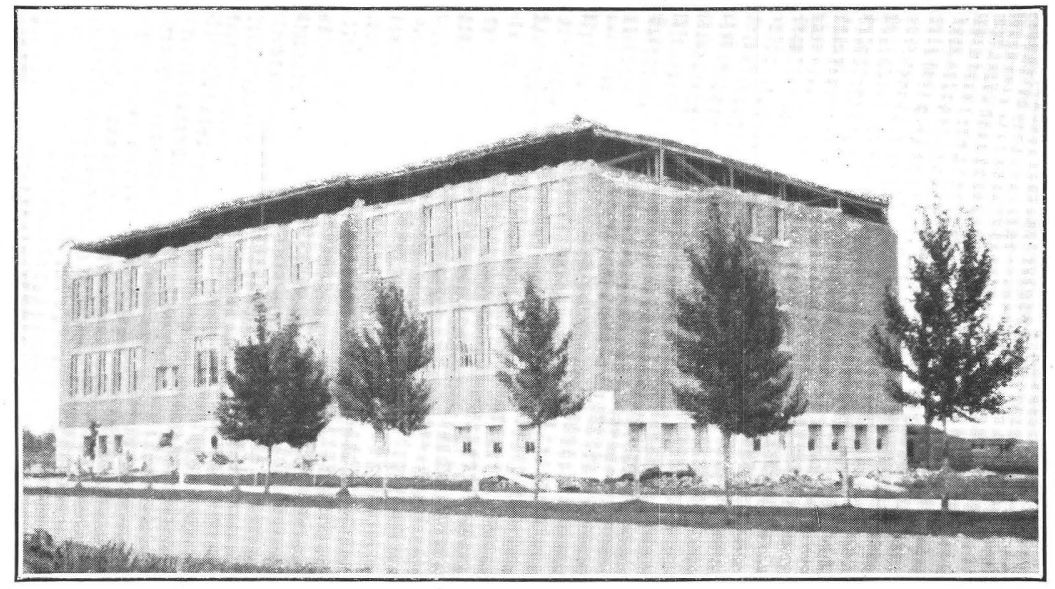

A. DAMAGED SCHOOLHOUSE AT THREE FORKS, MONT.

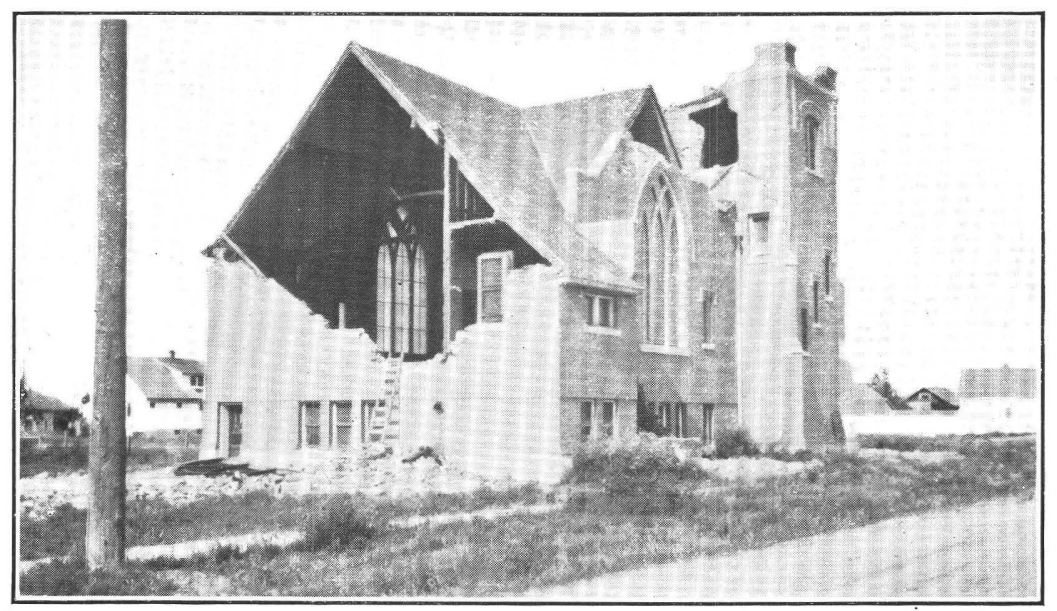

B. WRECK OF CHURCH AT THREE FORKS, MONT.

Note separation of the fallen bricks from one another due to failure of mortar 


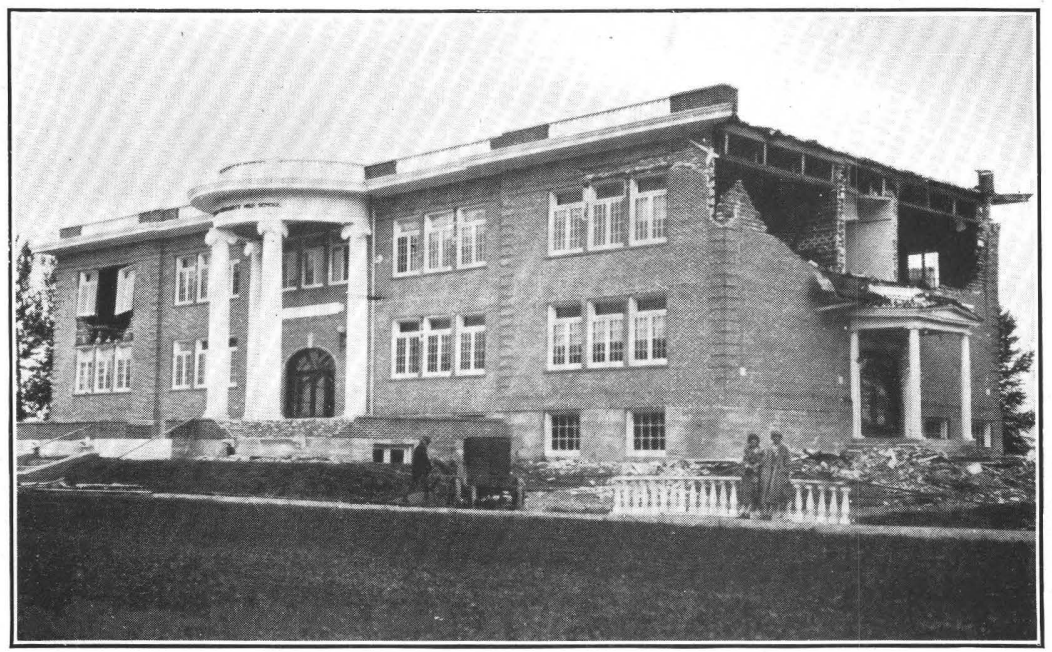

A. DAMAGED SCHOOLHOUSE AT MANHATTAN, MON'T.

Note separation of partition walls from outside wall due to lack of ties

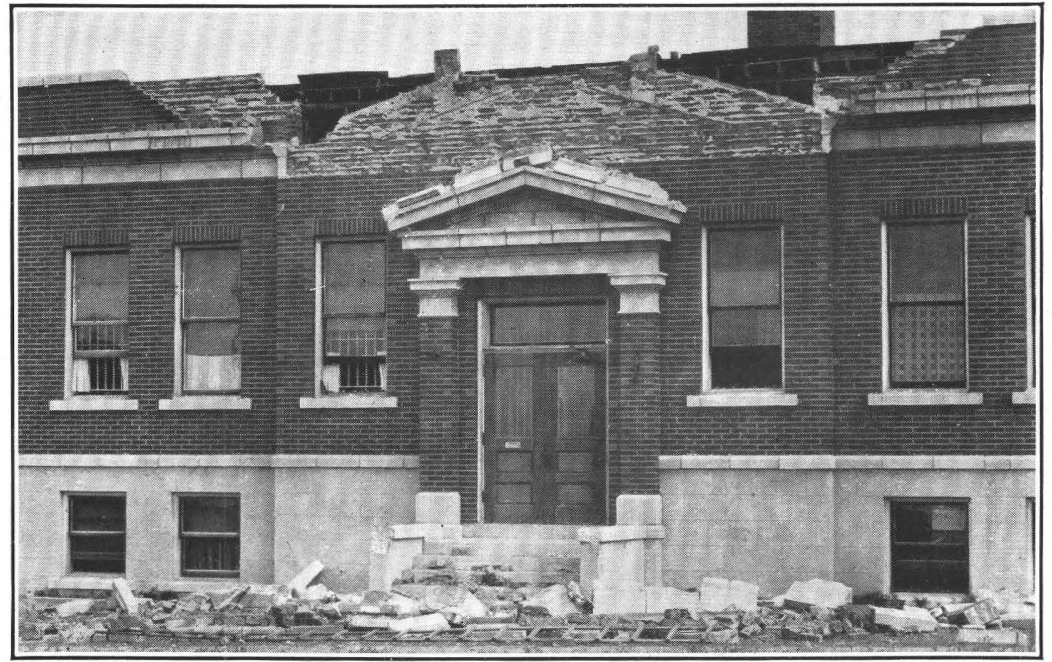

B. DAMAGED JAIL AT WHITE SULPHUR SPRINGS, MONT.

Note shearing of brick veneer from back wall 


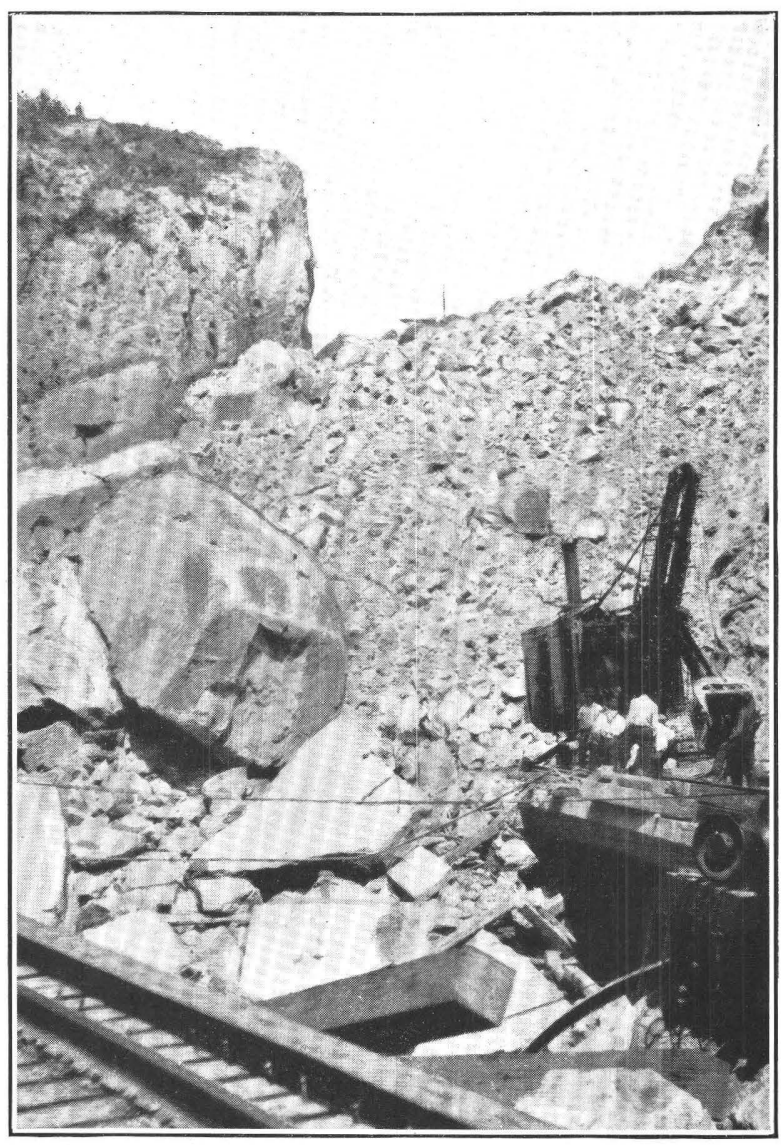

A. ROCK SLIDE NEAR DEER PARK, MONT. Temporary track in left foreground

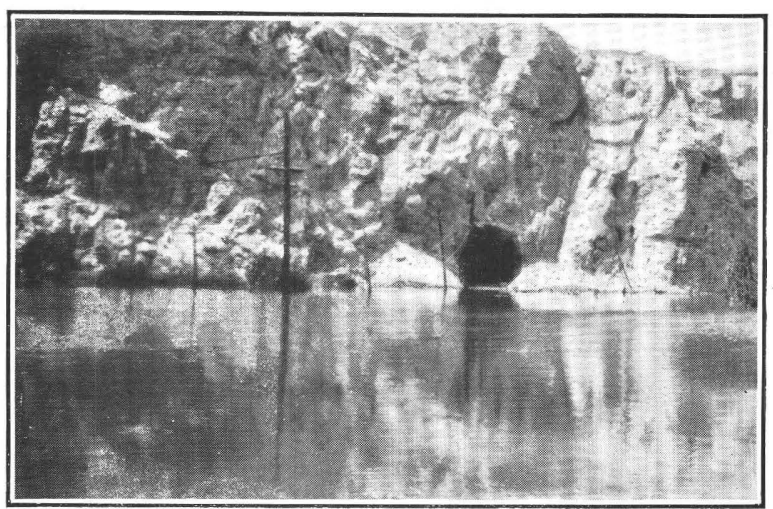

B. LAKE AT TUNNEL NO. 8, NEAR DEER PARK, MONT.

No rock falls occurred within the tunnel, Photograph by H. P. Allen 


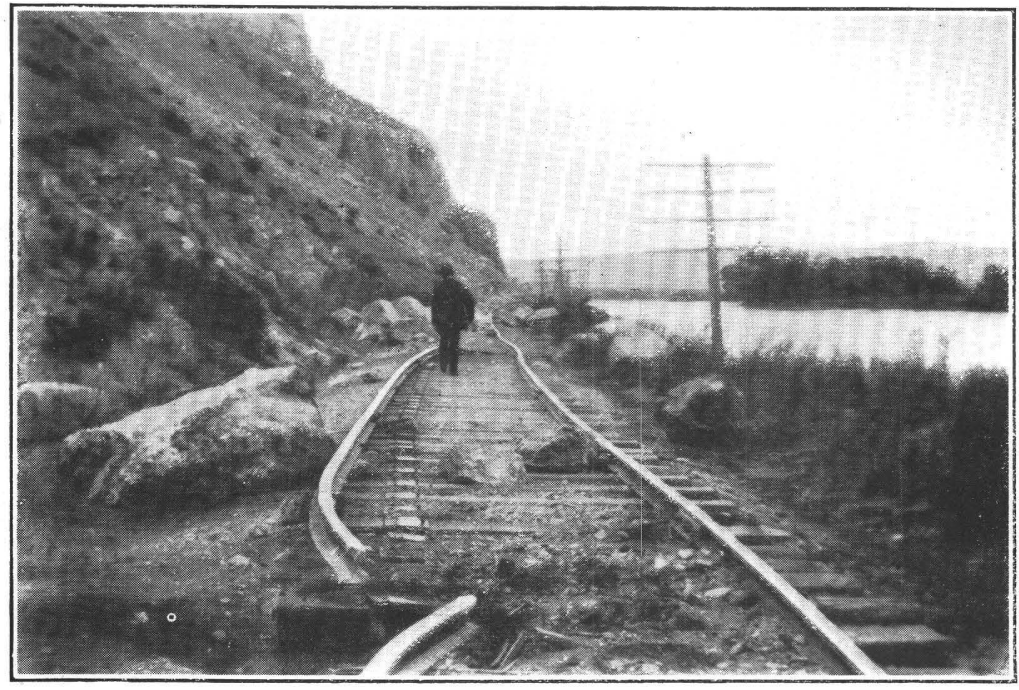

A. BROKEN RAILROAD TRACK NEAR LOMBARD, MON'T. Note rebound of the broken rail. Photograph by J. P. Swarts

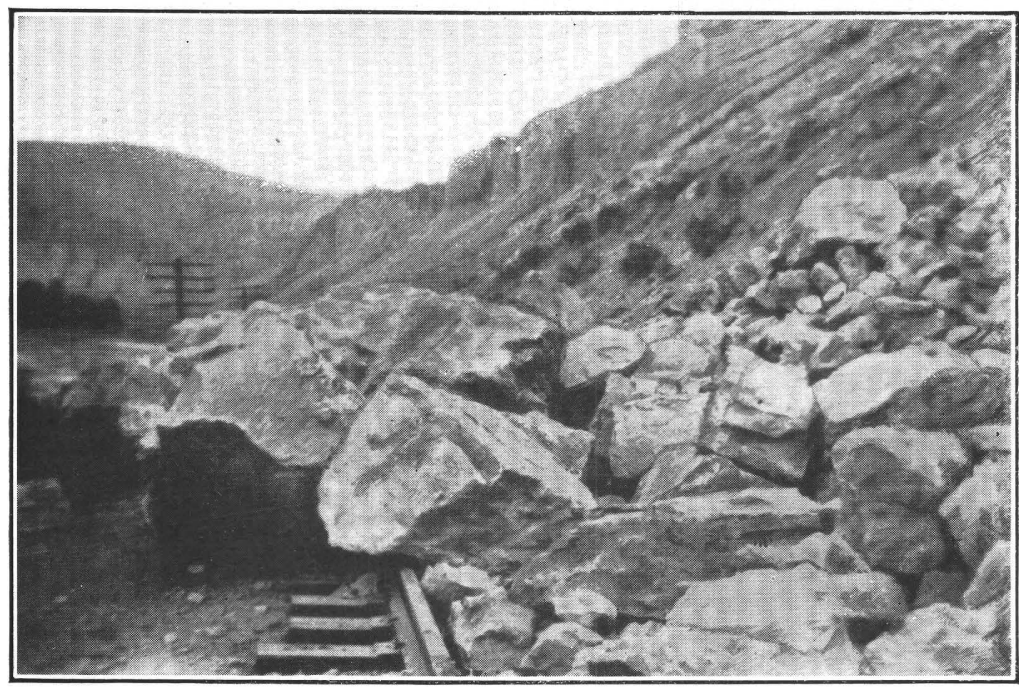

B. ROCKS ON RAILROAD TRACK NEAR LOMBARD, MON'I:

Photograph by J. P. Swarts 

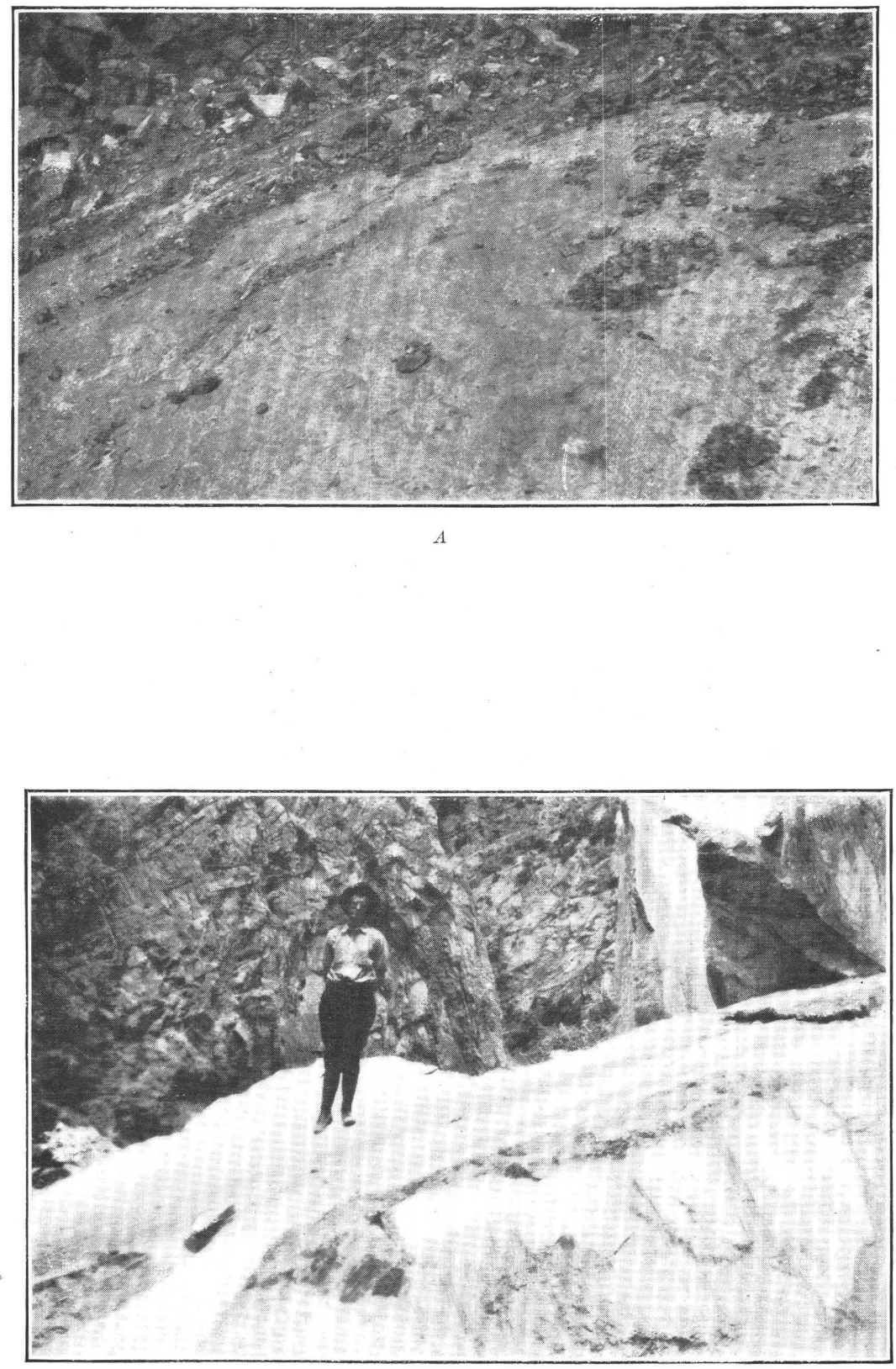

FAULT PLANE OF THE SLIDE NEAR DEER PARK, MONT,

Photographs by H. P. Allen 


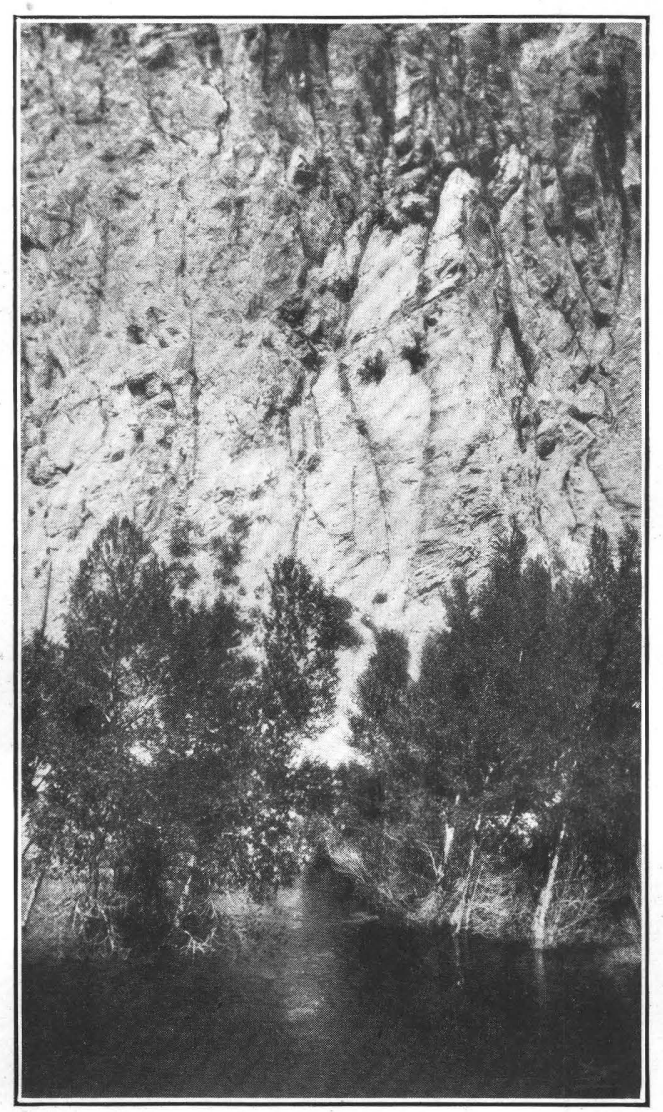

A. NORTH WALL OF GORGE BELOW DEER PARK, MONT.

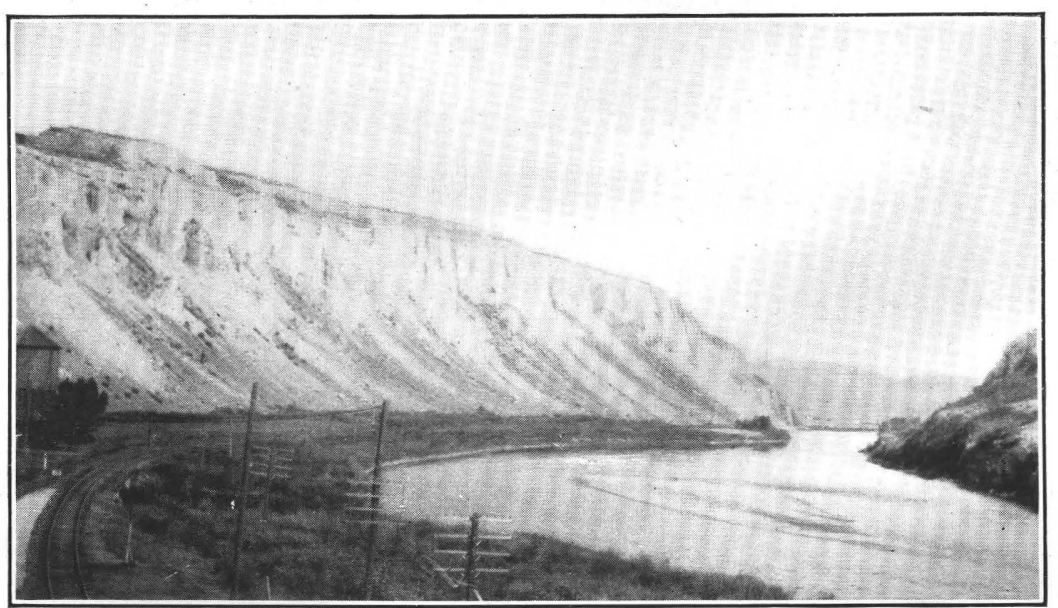

B. LIMESTONE CLIFFS AND TALUS SLOPE EAST OF MISSOURI RIVER AT LOMBARD, MONT.

Lighter-colored streaks on the talus slope represent débris shaken down by the earthquake 
U. S. GEOLOGICAL SURVEY

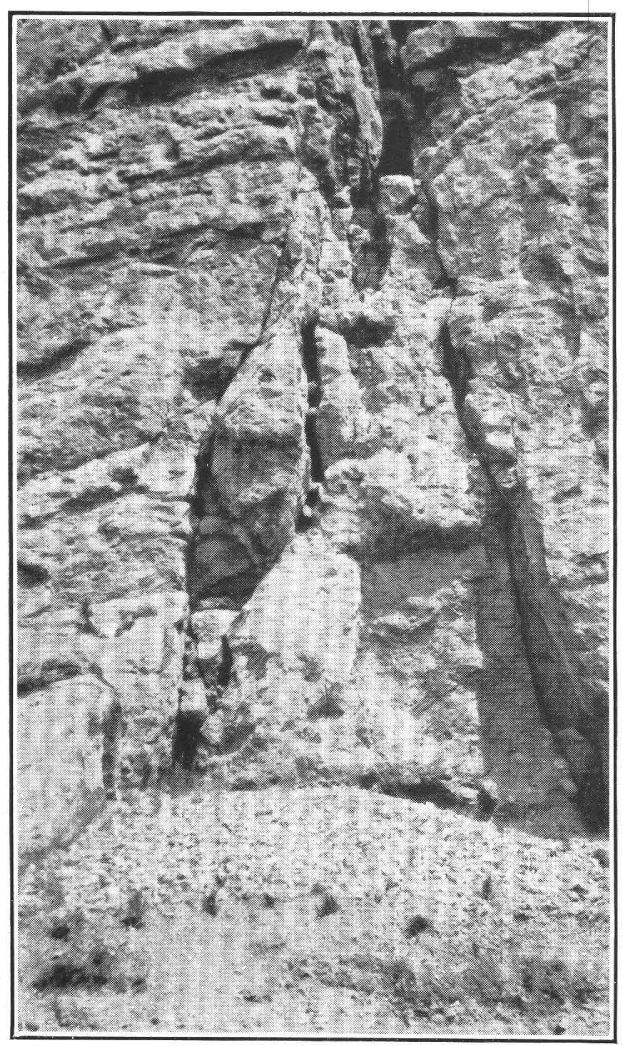

A. JOINTS IN LIMESTONE OPENED BY THE MONTANA EARTHQUAKE
PROFESSIONAL PAPER 147 PLATE 11

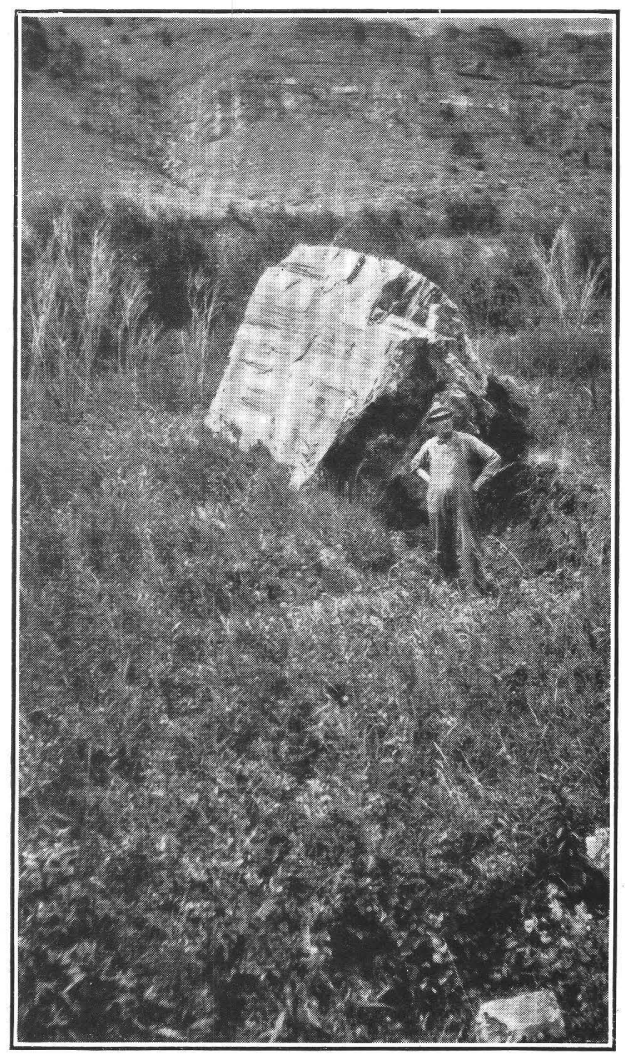

B. BOTTOM LAND ALONG MISSOURI RIVER, MONT. Boulder dislodged from a cliff by the earthquake and partly
buried by the force of its fall 


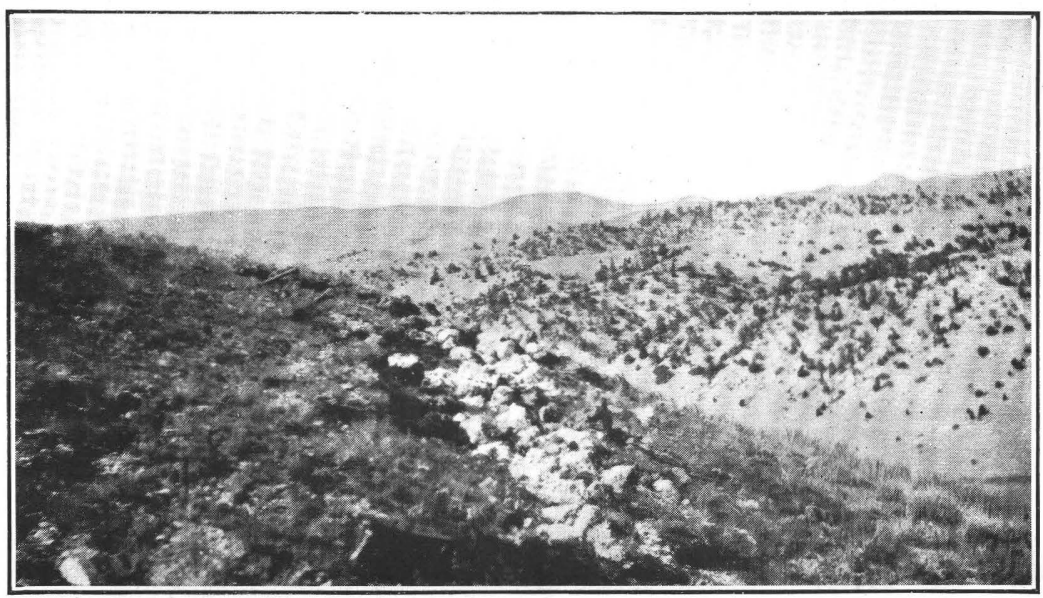

A. SHATTERED GROUND AND OVERTURNED CLODS, ROY GULCH, MONT.

The upturned clods show white because of a deposit of lime "caliche" just beneath the soil

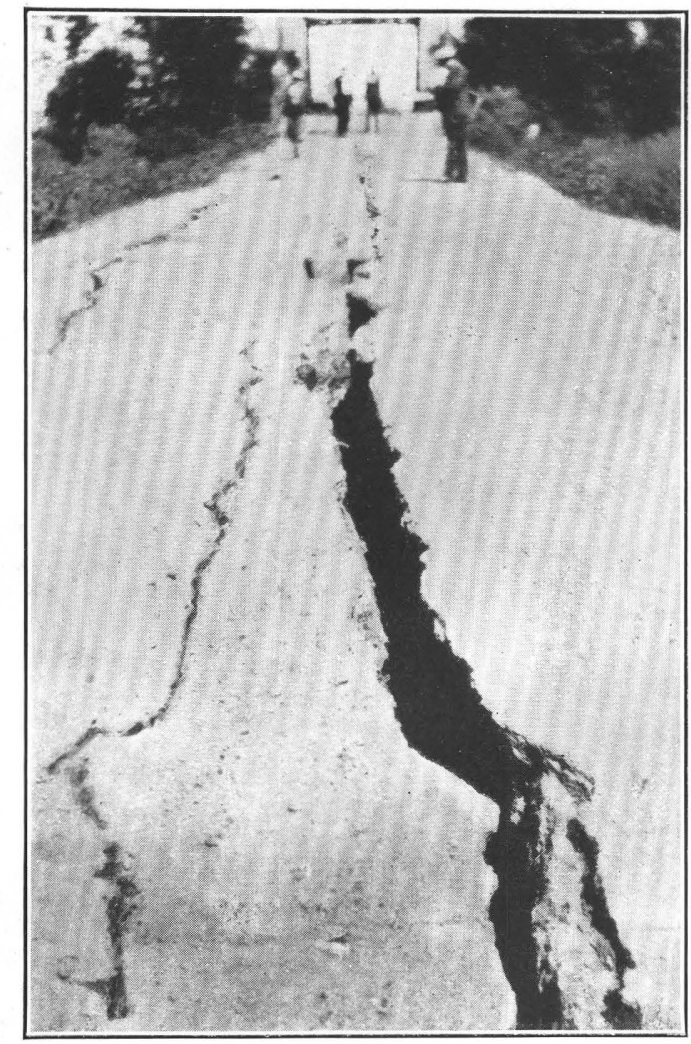

B. CRACK IN ROAD EMBANKMENT NORTH OF THREE FORKS, MONT. 


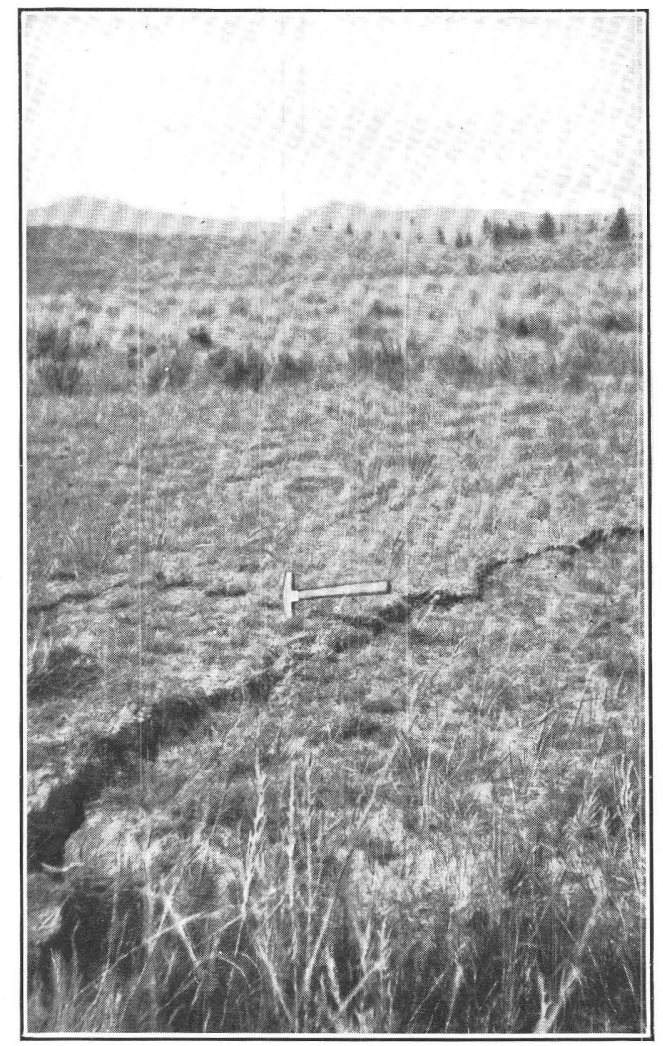

A. GROUND CRACK NEAR CANYON FERRY, MONT

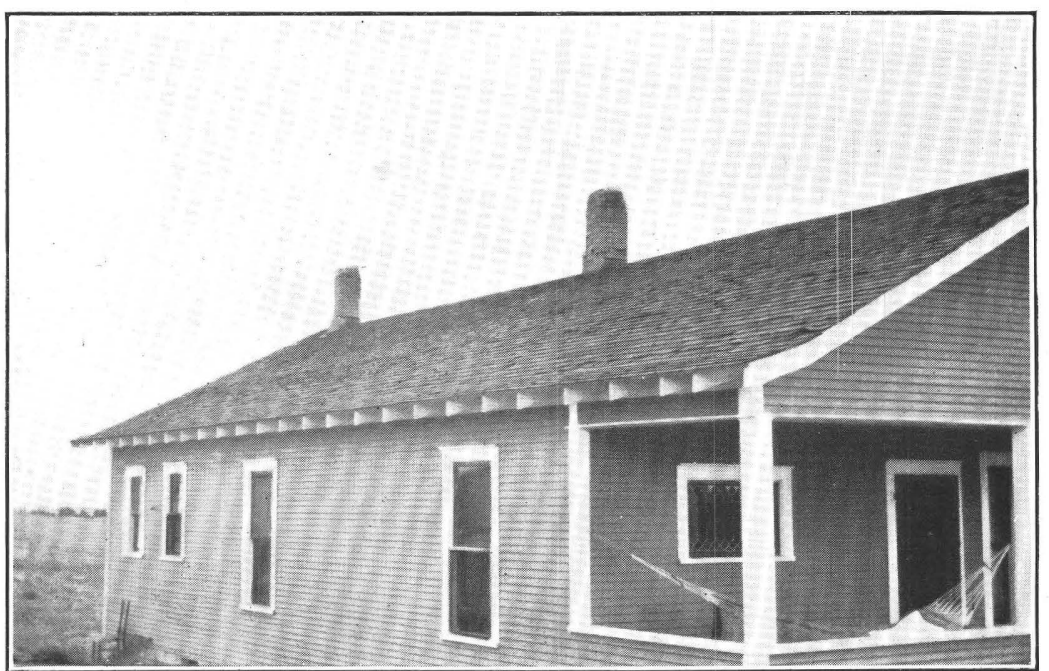

B. TWISTED CHIMNEYS AT LOGAN, MONT. 
the earthquake. Presumably the water was diverted to some other underground channel. Big Spring, ${ }^{2}$ above Toston, was said to have been muddy for two days, and the flow of Mockel Spring, ${ }^{3}$ south of Radersburg, was considerably increased. Increased flows of hot water are reported by the proprietors of White Sulphur Springs and Alhambra Springs, at Clancy. In the valley of Jefferson River, near Willow Creek, several new springs are said to have broken out, though existing springs went dry. According to press reports, a spring having a flow estimated on July 20 at 100 gallons a minute broke out in a field near Lewistown shortly after the earthquake.

\section{RENEWED FLOW OF OIL AND GAS}

An oil well near Cody, Wyo., that had been unproductive for several years "blew" considerable gas and oil for a few days after the earthquake. This well, which probably is the one described in published reports ${ }^{4}$ as Shoshone Oil Co.'s well No. 1, is situated north of Shoshone River, 3 miles east of Cody. It was bored in 1909-1912 to a depth of 1,720 feet and found gas and small amounts of oil in several different layers. Its total production, however, probably did not exceed 200 barrels. The well is about 300 feet north of the Cody branch of the Chicago, Burlington \& Quincy Railroad and 300 feet east of Cottonwood Creek. W. O. Taylor, of Cody, who witnessed the recurrence of activity, reports that the well started flowing about noon of the day after the earthquake. By the middle of the afternoon the flow had reached such proportions that the fire hazard appeared too great for trains to pass. Throughout the afternoon the well threw a column of mixed oil and water accompanied by gas from 30 to 40 feet in the air. The flow of gas was estimated at about 5,000,000 cubic feet a day, and the oil and water together at 1,500 barrels a day, the proportion of oil ranging from 5 to nearly 100 per cent. At 7 o'clock the next morning (June 29) the well was still spouting 10 or 15 feet in the air and making considerable oil. At 9 o'clock the flow had ceased. As a result of the well's activity the ground had become oil soaked for 100 feet around it.

Since the spurt described the well has remained quiet, and at the time of Mr. Taylor's report (Dec. 19,

\footnotetext{
2 Idem, p. 46.

${ }^{3}$ Idem, p. 47.

4 Hewett, D, F. The Shoshone River section, Wyo: U. S. Geol. Survey Bull. 541, pp.110-111, 1914. Hewett, D. F., and Lupton, C. T., Anticlines in the southern part of the Big Horn Basin, Wyo.: U. S. Geol. Survey Bull. 656, pp. 187-188, 1917.
}

1925) oil stood in the casing about 60 feet below the top.

Edwin Binney, jr., of New Haven, Conn., who visited the scene about three weeks after the earthquake, observed evidences of the recent activity of the well as described. Mr. Binney saw the same well in 1924. At that time it was discharging a small amount of gas, and oil was standing in it to the depth of at least 100 feet. The writer is indebted to $\mathrm{Mr}$. Binney for calling his attention to the behavior of this well and suggesting its possible relation to the earthquake.

The well is within the zone in which the earthquake intensity ranged from 4 to 5 on the Rossi-Forel scale. The Byron, Garland, and Elk Basin oil fields in Wyoming, and the Cat Creek and Kevin-Sunburst oil fields, in Montana are also in the same zone; the Salt Creek and other fields in Wyoming are in zones of less intensity. It is not known whether any wells in these fields were affected by the earthquake.

\section{SAND SPOUTS}

At Clarkston, in the alluvial bottom lands along Missouri River, a crack opened and sand and water spouted up for several hours. Afterward the crack closed, and at the time of the writer's visit, two months later, nothing could be seen but the deposit of sand spread over a square rod or two. Similar occurrences were reported near Townsend and in the horseshoe basin west of Menard, where water and mud are said to have spouted up like a geyser.

\section{INTENSITY OF THE EARTHQUAKE}

The intensities of the earthquake at different places, as shown by the following table, were estimated by the writer from the visible effects upon buildings and natural objects; reports obtained by letter or interview from persons who experienced the shocks, reports made by observers of the United States Weather Bureau, and reports published in the newspapers. Altogether 110 reports were obtained by interviews with persons who were within a radius of 40 or 50 miles of the epicenter. Sixty-five replies were received to letters addressed to postmasters or others in the outlying parts of the disturbed area, and a score or more of reports from scattered points were obtained from Weather Bureau observers and selected from the newspapers. 
[Principal shock at 6.21 p. m.]

Place $a$
Cardinal__.
Stockburger's, $21 / 2$ miles north-
east of Cardinal.
Deer Park
Garden Gulch, 4 miles south-
east of Lombard.
Dave Johnson's, 3 miles north
of Cardinal.
Lombard.....

Perugin's, 9 miles southeast of Townsend.

Jacobs's, 10 miles southeast of

Townsend.

Denzer's, 8 miles southeast of Townsend.

Roy Stillman's, 7 miles southwest of Maudlow.

Trident

Three Forks

Manhattan.

Logan

Toston

Mockel's, 7 miles south-southeast of Radersburg.

Valley of Madison River, 8 miles south of Three Forks.

Gallatin Valley, 3 miles south of Manhattan.

Maudlow _...............

Accola

Menard

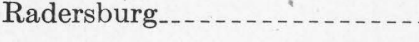

Walbert's, 9 miles north-northwest of Three Forks.

Doherty's, 6 miles east-southeast of Townsend.

Thompson's, 6 miles east of Townsend.

Townsend...................

Willow Creek.

Steingruber's, 4 miles north of Willow Creek.

Belgrade_._._._._._._._._.

Carroll's, 9 miles southeast of Maudlow.

Helena_....................

Whitehall

Jefferson Island

\begin{tabular}{|c|c|c|c|}
\hline \multicolumn{2}{|c|}{$\begin{array}{l}\text { Latitude } \\
\text { N. }\end{array}$} & \multicolumn{2}{|c|}{$\begin{array}{c}\text { Longitude } \\
\text { W. }\end{array}$} \\
\hline 。 & ' & 。 & , \\
\hline 46 & 7 & 111 & 22 \\
\hline 46 & 8 & 111 & 20 \\
\hline 46 & 8 & 111 & 19 \\
\hline 46 & 6 & 111 & 20 \\
\hline 46 & 9 & 111 & 21 \\
\hline 46 & 8 & 111 & 24 \\
\hline 46 & 15 & 111 & 22 \\
\hline 46 & $\underset{15}{2}$ & 111 & 24 \\
\hline 46 & 17 & 111 & 23 \\
\hline 46 & 4 & 111 & 17 \\
\hline 45 & 57 & 111 & 29 \\
\hline 45 & 58 & 111 & 33 \\
\hline 45 & 53 & 111 & 26 \\
\hline 46 & 10 & 111 & 26 \\
\hline 46 & 8 & 111 & 36 \\
\hline 45 & 46 & 111 & 32 \\
\hline 45 & 50 & 111 & 20 \\
\hline 46 & 8 & 111 & 10 \\
\hline 45 & 54 & 111 & 13 \\
\hline $\begin{array}{l}45 \\
46\end{array}$ & $\begin{array}{l}58 \\
13\end{array}$ & $\begin{array}{l}111 \\
111\end{array}$ & $\begin{array}{l}12 \\
39\end{array}$ \\
\hline 46 & 2 & 111 & 38 \\
\hline 46 & 18 & 111 & 25 \\
\hline 46 & 19 & 111 & 25 \\
\hline 46 & 20 & 111 & 32 \\
\hline 45 & 40 & 111 & 39 \\
\hline 45 & 53 & 111 & 39 \\
\hline 45 & 2 & 111 & 11 \\
\hline 46 & 2 & 111 & 6 \\
\hline 46 & 36 & 112 & 0 \\
\hline 45 & 48 & 112 & 6 \\
\hline 45 & 47 & 111 & 57 \\
\hline
\end{tabular}

Effects, etc.

Inten-

9+ Extensive rock falls from cliffs. Heavy stove moved east.

$9+$ Furniture in small house thrown violently about. Cracks in ground. Log buildings distorted and made to lean eastward.

9+ Extensive rock falls and slides. Heavy stove moved northwest. Other furniture in small house thrown about.

$9+$ Loose clods in plowed field "danced and shuffled about." Stove in cabin thrown over eastward. Log cabin sprung out of shape.

$9+$ Ground cracks. All loose objects in small frame house thrown about violently.

$9+$ Extensive rock falls. Telephone poles leaned strongly to the northwest, then righted. Heavy steel safe in Northern Pacific Railway depot moved to the southeast. Strong surge on Missouri River. Swells formed on railway track.

9 Doors of stove jerked off.

$9+$ Ground cracks and sand spout. Visible ground waves.

9 Small frame house distorted. Furniture thrown about.

$9+$ Doors jerked off of hinges. Furniture, etc., thrown about and wrecked. Ground cracks.

$9 \quad$ All loose articles in small house thrown about.

$9 \quad$ All chimneys broken or thrown down. Cement walls and foundations seriously damaged.

9 Brick and stone buildings seriously damaged; some partly wrecked.

9 Several brick and stone buildings seriously damaged; some partly wrecked.

9 Brick schoolhouse partly wrecked. Chimneys generally overthrown.

9 Many chimneys overthrown. Piano moved eastward. Loose articles on shelves fell eastward.

$8+$ Chimneys overthrown.

8 Rock falls. Chimneys overthrown. Cracks opened in cliffs. Water thrown out of troughs.

$8+$ Chimneys overthrown.

8 Some chimneys overthrown. Loose articles fell from shelves.

$8+$ Rock falls.

$8+$ Chimneys overthrown.

$8+$ Chimneys overthrown. Some brick and stone buildings seriously damaged.

$8+$ Visible ground waves. Water thrown out of trough.

$8+$ Heavy tractor thrown south off the timbers on which it had been blocked up. Chimneys overthrown.

$8+$ Doors on one-story frame house swung violently. Loose articles fell.

$8+$ Loose articles thrown from shelves. Doors and lights swung violently. Some chimneys overthrown.

$8+$ Brick schoolhouse seriously damaged. Some chimneys overthrown. Plate-glass windows broken. Visible earth waves. Goods spilled from shelves on north and south sides of room. Few articles on west side down.

8 Loose articles thrown about. Rock falls.

8 Cornice on brick schoolhouse fell. Some chimneys overthrown. Brick and stone walls cracked.

8 Loose articles thrown from shelves. Chimneys broken.

7 Slight damage to some buildings and a few chimneys wrecked. Loose articles fell from shelves in several stores.

7 Top of a two-story brick wall fell off on west side. Chimneys damaged. Some loose articles fell from shelves. Automobiles facing east and west in a garage rolled forward and back in unison.

7 Buildings and other objects swayed alarmingly.

a Localities in Montana except as indicated otherwise.

${ }^{b}$ The figures indicating intensity are those of the Rossi-Forel scale, which as published in the Bulletin of the Seismological Society of America (vol. 11, p. 218) is as

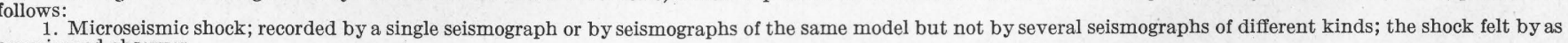
experienced observer.

2. Extremely feeble shock; recorded by several seismographs of different kinds; felt by a small number of persons at rest.

3. Very feeble shock; felt by several persons at rest; strong enough for the direction or duration to be appreciable.

4. Feeble shock; felt by persons in motion; disturbances of movable objects, doors, windows; creaking of ceilings.

5. Shock of moderate intensity; felt generally by everyone; disturbance of furniture, beds, etc., ringing of swinging bells.
6. Fairly strong shock; general awakening of those asleep; general ringing of house bells; oscillation of chandeliers; stopping of pendulum clocks; visible agitation of trees and shrubs; some startled persons leave their dwellings.

7. Strong shock; overthrow of movable objects; fall of plaster; ringing of church bells; general panic, without damage to buildings.

8. Very strong shock; fall of chimneys; cracks in walls of buildings.

9 . Extremely strong shock; partial or total destruction of some buildings.

10. Shock of extreme intensity; great disaster buildings ruined; disturbance of the strata; fissures in the ground; rock falls from mountains. 
Intensity and effects of Montana earthquake of June 27, 1925-Continued

[Principal shock at 6.21 p. m.]

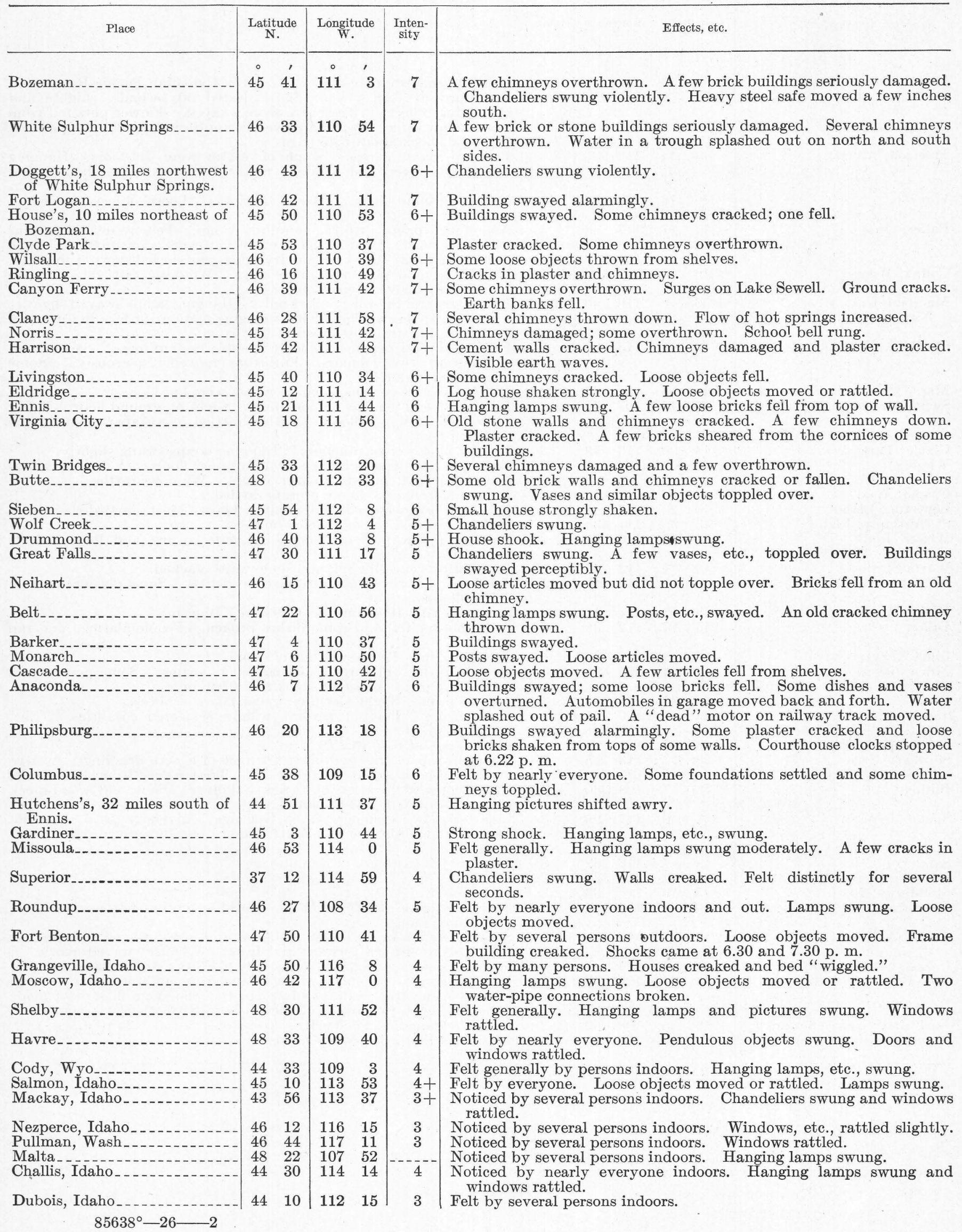


[Principal shock at 6.21 p. m.]

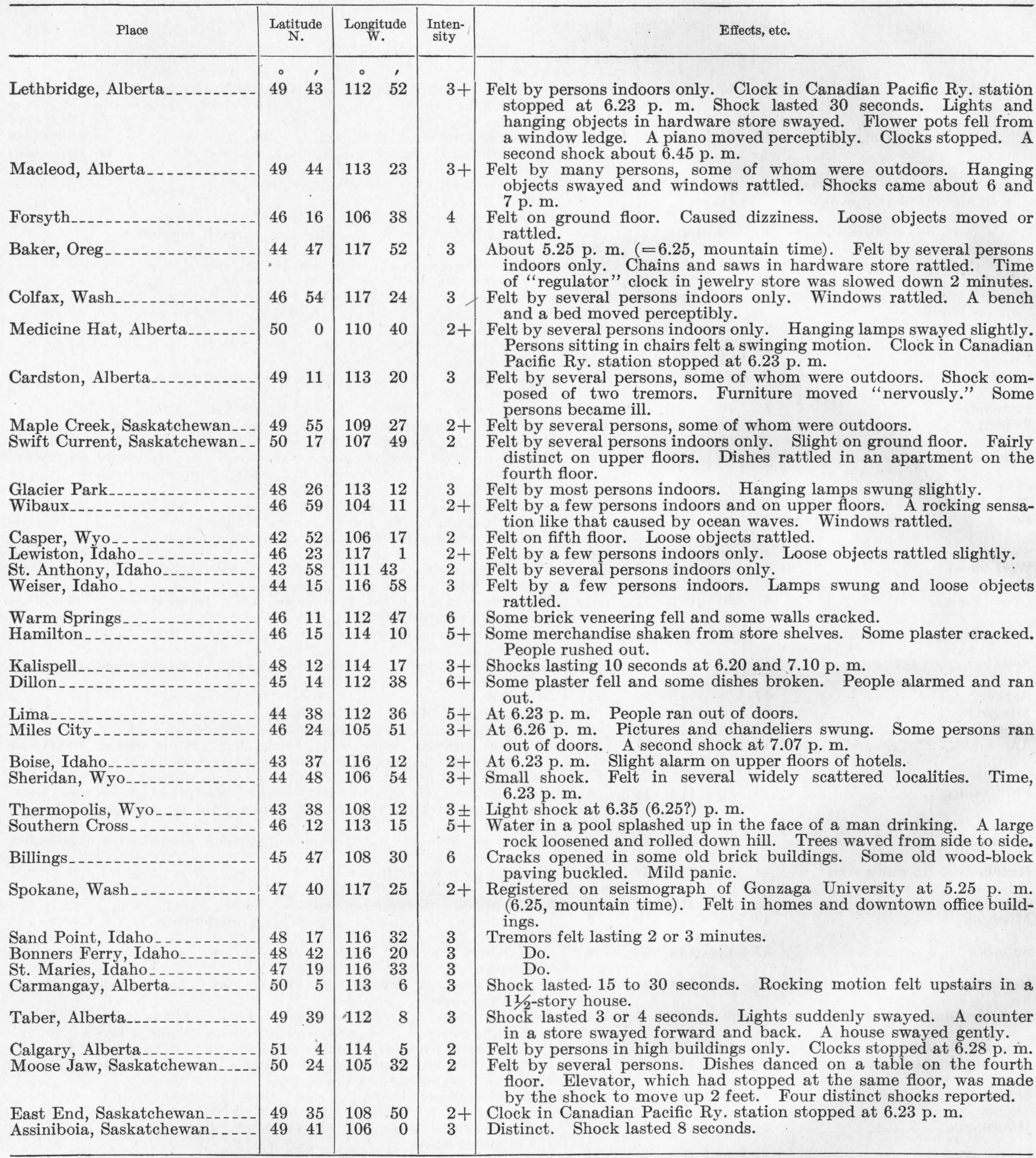


Negative reports were received from the following places:

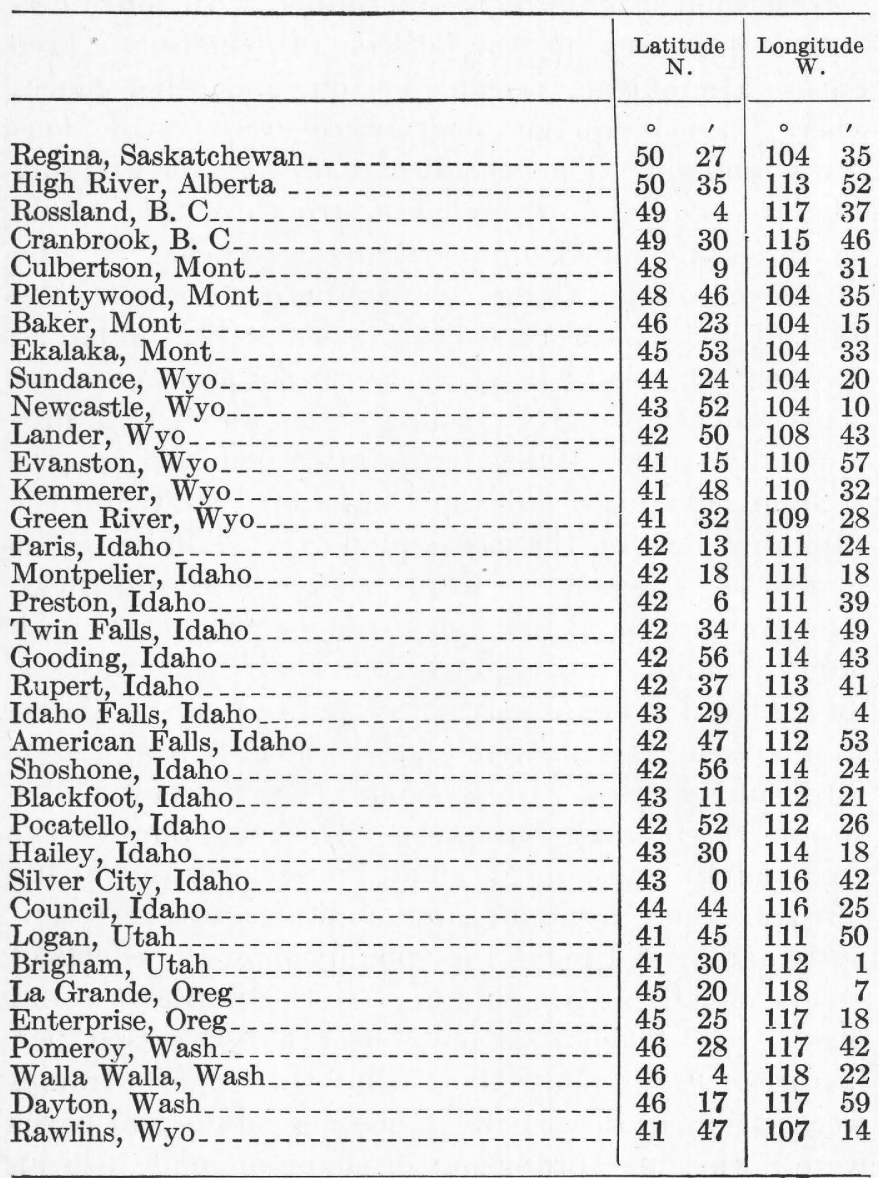

DIRECTION OF THE MOTION

Positive evidence as to the direction in which the vibrations traveled is given by the operator of the Chicago, Milwaukee \& St. Paul Railway at Jefferson Island. He was working on the train dispatcher's telephone at the time and heard the operator at Three Forks say they were having an earthquake. In a few seconds he felt it himself, and still later he heard it reported by the operator at Butte. In a straight line Three Forks is 20 miles east of Jefferson Island and Butte 30 miles to the west. Near Toston during the earthquake an observer in an automobile traveling on a road leading southeastward, or toward the epicenter, noticed nothing unusual in the behavior of his car. Another traveling in a northeasterly direction had difficulty in keeping his car on the road, presumably because he was traveling crosswise to the direction of motion. Many of the observers reported the direction that the earthquake waves seemed to travel, and most of these directions, whether leading toward or away from the epicenter, when platted on the map, coincide nearly with radii.

$$
22958^{\circ}-27-2
$$

\section{NATURE OF THE MOTION}

Observers near the epicenter describe the earthquake motion as a violent bumping and rocking. Elsewhere practically all describe it as a rocking motion, which a few qualify with the terms bumping, jerking, or twisting. Visible ground waves, much like the swell in the wake of a steamboat, were reported by many persons. Similar waves were indicated by the behavior of buildings, fences, telegraph poles, etc., which were observed to lean to one side and then to the other, describing ares of as much as $30^{\circ}$. Standing automobiles, including a heary tractor, were seen to dance a comical sort of jig, rising first on one side then on the other. At Three Forks a frame house appeared to buckle up along the comb of the roof, like a cat humping its back at sight of a dog, and then straighten out again without being seriously damaged. At Willow Creek an observer was able to see clear under a house momentarily as one end lifted clear of the foundation and settled back to place.

At Radersburg, Logan, and other places some chimneys were broken at the roof line and twisted clockwise one-eighth to one-quarter of a revolution (pl. 13, B).

\section{SOUNDS}

Sounds of low pitch were heard by 80 per cent of the observers who were within 25 miles of the epicenter, and by 65 per cent of those within 80 miles. Beyond that distance only 30 per cent of the observers report sounds, but information from this outlying belt is too scanty to fix the limit of the sound area. The great majority of the observers describe the sounds as a low rumbling, and several add that it was like a train or a heavy truck passing by or crossing a bridge, or like thunder. A few describe the sound as a roaring, a rushing or swishing like the wind, or like a storm or a low growl.

\section{AREA}

The area throughout which the shock was sensible to persons, which is the area bounded by isoseismal 2 (see pl. 3) is about 310,000 square miles. The disturbed area is therefore of about the same order of magnitude as that of tectonic earthquakes of the first rank. The intensity of the Montana disturbance was apparently somewhat less than that of the California earthquake of 1906, and the damage, owing, as already explained, to the lack of populous cities near the epicenter, was comparatively insignificant.

\section{TIME AND DURATION}

The time at which the main shock occurred is reported variously from 6.15 to $6.35 \mathrm{p}$. m., but 70 per cent of the observers set the time between 6.20 and 
$6.25 \mathrm{p} . \mathrm{m}$. Of those who were within a radius of 50 or 60 miles from the epicenter 60 per cent reported the time as either 6.20 or 6.21 p. m., the weight of evidence, all things considered, being much in favor of 6.21. Clocks stopped at that time in a drug store at Three Forks and in the office of the United States Weather Bureau at Helena. Outside the area described, 12 observers out of a total of 24 place the time at 6.23 and 4 at 6.25 ; the remainder are scattering.

Estimates of duration reported by 66 persons range from 5 seconds to 3 minutes, but about three-fourths of the estimates lie between 15 seconds and 1 minute, and their average is about 30 seconds. No one reported having timed the shock with a watch or other instrument, but within the area of startling shock the duration was at least 15 or 20 seconds, for in less time the observers could hardly have traversed the distances or performed the tasks that they claimed to have done while the shaking was in progress. Apparently in outlying areas where the intensity was moderate or feeble the sensible vibrations continued for 30 seconds or more.

\section{SPEED OF TRANSLATION}

Clocks in Canadian Pacific Railway stations at Lethbridge and Medicine Hat, Alberta, and East End, Saskatchewan, stopped at 6.23 p. m. A Western Union clock at Glasgow, Mont., was reported stopped also at that time. The distance of these places from the epicenter ranges from 264 miles for Lethbridge to 276 miles for Medicine Hat. If the times as given for these places and for the epicenter are accepted as correct, then the vibrations were propagated outward an average distance of 270 miles in two minutes, or at the rate of $2 \frac{1}{4}$ miles a second. Owing to the fact, however, that the time observations were made to the nearest minute only, there remains the possibility of an error as great as one minute, plus or minus. Therefore, the total time of translation for the distance mentioned may be as short as one minute or as long as three minutes, and the speed at which the vibrations traveled lies between $41 / 2$ and $11 / 2$ miles a second.

\section{ISOSEISMALS 5 \\ DATA AVAILABLE}

Compared to the size of the disturbed area the number of observations available is rather small, and therefore the isoseismal lines as drawn (pl. 3) doubtless appear more precise and definite than they should. Where their position is believed to be determined within rather narrow limits they have

\footnotetext{
5 "An isoseismal line, or simply an isoseismal, is a line drawn through all places at which the intensity of the shock is the same."-Davison, C., A manual of seismology, p. 4, Cambridge Univ. Press, 1921.
}

been drawn as full lines; where the evidence for placing them is less definite, they are represented by dashes.

Isoseismal 9 is perhaps determined with more certainty than any of the others. It incloses Three Forks, Manhattan, Logan, Toston, and other places where the earthquake effects were most conspicuous and abundant. The central part of this area is thinly inhabited and almost devoid of structures that would be easily damaged by earthquake shocks. If the effects on similar things are compared, however, the intensity seems to have been considerably higher in this central area than at Three Forks and the other places mentioned. Accordingly, an isoseismal provisionally labeled 10 has been drawn inclosing an area of about 80 square miles in Clarkston Valley and the adjoining hills on the east and north. Lombard, the largest settlement within this isoseismal, contains two railroad stations of one-story frame construction with brick chimneys and eight or ten small frame houses, some of which are merely converted box cars. Clarkston consists of a station, a grain elevator, and two or three small houses. Cardinal and Deer Park each have two or three small buildings. The remainder of the area contains only a few small houses of frame or log construction. None of these buildings was very seriously damaged, though they plainly show the effects of severe shaking. All chimneys were overthrown and plaster was broken in the few houses that possessed such features. Commonly door, window, or house frames were sprung or distorted. Some log cabins and barns were noticeably sprung out of shape or made to lean to one side. Some doors were jerked off their hinges. Furniture, including stoves and ranges, and other loose articles were overturned or thrown about, and in most houses practically every dish or other breakable article was demolished. The racking a small but substantial unplastered frame house at Cardinal suffered is shown by torn wall paper and lining. The intensity of the shock at Roy Gulch is indicated by the cracking and shattering of moderately firm ground and the overturning of clods (pl. 12, B). At Garden Gulch an observer saw the clods in a plowed field shuffled about like checkers being shaken on a board. Rock falls in this area have been described (pp. 9-10).

At Three Forks and other places outside the area being considered the overthrowing of furniture and the breaking of dishes were less general or complete and the springing or racking of door and house frames was rather exceptional. The crack that appeared in the road north of Three Forks opened in an artificial embankment not to be compared in resistance to the firm ground which was shattered at Roy Gulch. At Trident there are cliffs essentially similar to those at Lombard, but much less material was shaken down from them.

So far as the evidence goes, therefore, the shock appears to have been much stronger in this central 
area than elsewhere. After comparing effects in the field it is difficult to escape the conclusion that had a town such as Three Forks, for example, been situated here every brick building in it would have been leveled.

\section{POSITION OF THE EPICENTER}

The longer axis of the innermost isoseismal trends about N. $10^{\circ}$ E. and lies a little east of Cardinal, crossing the lower parts of Roy and Garden Gulches. Its position is not far from a line dividing T. $4 \mathrm{~N}$., R. 3 E., into east and west halves. The longer axis of the next isoseismal (No. 9) is parallel to that of the smaller curve, but it lies about a mile farther west. As nearly as can be determined, therefore, the epicenter lies either on one of these axes or between them and within a belt extending south 3 or 4 miles from Cardinal.

\section{FORM OF THE ISOSEISMALS}

As drawn isoseismal curves 7, 8, and 9 show a tendency to expand toward the west; possibly this is an erroneous interpretation, due to the lack of sufficient data or to undue weight having been given to the evidence from the more populous areas. Such a result has been guarded against as far as possible, however, and the expansion is believed to be real. It may possibly be due to the westward hade of the fault on which the earthquake is supposed to have originated, (see p. 22).

The three outer isoseismals show a striking irregularity at the south, where they are crowded inward so as to exclude a wide reentrant from the area of sensible shock. St. Anthony, Idaho, near the peak of this reentrant, is only 150 miles south of the epicenter, whereas in other directions the shock persisted for distances of 300 to 400 miles. This abrupt and abnormal decline of intensity begins at the edge of the Snake River Plain, a great valley floored with lava. Presumably the lava overlies a considerable thickness of unconsolidated sediments, and these in turn rest upon the upturned and eroded edges of older and harder rocks like those of the surrounding mountains. At the northeast the lava of the Snake River Plain merges with the lavas of Yellowstone Park, which consist of a great thickness of flows, tuffs, and breccias. The whole forms a heterogeneous mass that coincides suggestively with the zone in which the southward progress of the vibrations was arrested. At the west a similar indentation is indicated where the disturbed area touches the Columbia Plateau, but only isoseismals 2 and 3 are affected. Here the vibrations persisted somewhat beyond the edge of the lava, but there was a sudden and marked decline of intensity as soon as the main lava area was reached.

Columbia Plateau is made up of many lava flows, between some of which are beds of gravel or silt, the whole forming a mass of similar physical character to the rocks of the Snake River Plain and Yellowstone
Park. It would seem, therefore, that these rather loosely aggregated masses were able to break up and check the rather feeble vibrations that reached them. This explanation, however, becomes less certain when the fact is considered that toward the northeast the vibrations extended farther than anywhere else, though the region they traversed is underlain by rocks (Cretaceous sediments) that are not especially dense or homogeneous.

Both the Snake River Plain and the Columbia Plateau may be regarded as great structural depressions, and it is possible, therefore, that the vibrations were cut off or deflected by bordering fault zones, but there are many similar though smaller structural features within the disturbed area that do not seem to have hindered the tremors at all.

\section{FORESHOCKS}

Although 80 per cent of the observers report the onset of the main shock as rapid or abrupt, without any warning, the remainder felt a preliminary quiver which, according to several persons, was separated from the main shock by a brief pause. Reports of this preliminary tremor which may possibly be classed as a foreshock, were obtained at places well distributed through an area measured by a radius of 125 miles from the epicenter. Doubtless the failure of most observers to notice it was due to lack of experience. Many of the shocks that were rather generally observed after June 27 were probably of no greater intensity.

An interesting foreshock occurred May 31, reports of which were obtained from five observers. At Lombard this shock, as timed by J. P. Swarts and W. P. Luburg, Northern Pacific Railway operators, occurred at 7.55 a. $\mathrm{m}$. Loose articles in a small frame house (a converted box car) moved or rattled, and a doorframe was sprung slightly. At the same time another observer, Arthur Jersey, who was walking in the hills 3 miles northwest of Sixteen, felt a shock in which the ground seemed to rise suddenly and then settle back and quiver a little. At Menard the same shock, as reported by Mrs. A. R. Hill, made things rattle, and according to W. T. Lathrop, two light shocks were felt in the office of the United States Weather Bureau (sixth floor) at Helena, and in a residence at Kenmore. Lombard is a short distance northwest, Menard 12 miles southeast, Sixteen 20 miles northeast, and Helena about 50 miles northwest of the epicenter of the earthquake of June 27. Apparently the shock of May 31 emanated from the same center.

\section{AFTERSHOCKS}

A great many aftershocks were felt at Three Forks, Manhattan, and other places near the epicenter, and several of them were perceptible also at more distant 
points. The ground is said to have been in an almost continuous tremble during the night of June 27 at Lombard, Deer Park, and similarly situated places. At Trident sensible shocks are estimated to have averaged four a day for the first month and two a day for the second month after the earthquake. Between June 27 and July 6 a record was kept by A. D. Burkett of 52 shocks that were strong enough to be felt by nearly everyone. The total number of aftershocks recorded prior to August 14 is about 75 .

The strongest aftershock and the first one to be generally observed occurred at 7.10 p. m., or about three-quarters of an hour after the main shock. It was more or less distinct over a large area, most of the observers in which describe it as being nearly, if not quite, as strong as the main shock but of somewhat shorter duration. It caused additional rock falls, threw down some more chimneys, and caused many brick walls that had been loosened by the first shock to topple over. It came on very abruptly, accompanied by a deep rumble or roar, and caused renewed and increased alarm among the inhabitants.

This shock was felt at Miles City, 270 miles east, at Macleod, Alberta, 270 miles north, and at Kalispell, 200 miles northwest of the epicenter. On the south the most distant point reporting it is Hutchens, on Madison River, 75 miles from the epicenter. There the intensity was between 3 and 4 . The shock is thus indicated to have been sensible throughout an area of nearly 200,000 square miles. The available records are tabulated below:

Summary of reports of aftershock of the Montana earthquake of June 27, 1925, occurring at 7.10 p. m. mountain time

\begin{tabular}{|c|c|c|c|c|c|c|}
\hline Place ${ }^{\circ}$ & \multicolumn{2}{|c|}{$\begin{array}{l}\text { Latitude } \\
\text { N. }\end{array}$} & \multicolumn{2}{|c|}{$\begin{array}{l}\text { Longitude } \\
\text { W. }\end{array}$} & $\begin{array}{l}\text { Inten- } \\
\text { sity }\end{array}$ & Remarks \\
\hline Townsend. & & & & 32 & 8 & Clock stopped 7.10 p. m. Duration 30 seconds. Almost as strong \\
\hline Deer Park_. & 46 & 8 & 111 & 9 & $9+$ & Short but so violent persons could not stand alone. \\
\hline $\begin{array}{l}\text { Dave Johnson's, } 3 \text { miles north } \\
\text { of Cardinal. }\end{array}$ & 46 & 9 & 111 & 21 & 9 & Shorter than first shock. \\
\hline $\begin{array}{l}\text { Stockburger's, } 21 / 2 \text { miles north- } \\
\text { east of Cardinal. }\end{array}$ & 46 & 8 & 111 & 20 & $9+$ & Seemed longer than first shock. \\
\hline Butte $\ldots \ldots \ldots$ & 46 & 0 & 112 & 33 & $5 \pm$ & Duration 40 seconds. \\
\hline Manhattan & $\begin{array}{l}45 \\
45\end{array}$ & $\begin{array}{l}53 \\
52\end{array}$ & $\begin{array}{l}111 \\
111\end{array}$ & $\begin{array}{l}26 \\
20\end{array}$ & $\begin{array}{l}9+ \\
9+\end{array}$ & Seemed harder than first shock. Bricks fell at schoolhouse. \\
\hline Three Forks_ & 45 & 53 & 111 & 53 & $9+$ & $\begin{array}{l}\text { Abrupt and harder than first shoek but shorter. Some persons stand- } \\
\text { ing were thrown down. Most of the brick fell from church at this } \\
\text { time. }\end{array}$ \\
\hline Trident & 45 & 57 & 111 & 29 & $9+$ & Seemed stronger than first shock. \\
\hline $\begin{array}{l}\text { Roy Stiilman's, } 7 \text { miles south- } \\
\text { west of Maudlow. }\end{array}$ & 46 & 4 & 111 & 17 & $9+$ & Abrupt but shorter than first shock. \\
\hline $\begin{array}{l}\text { Jacobs's, } 7 \text { miles southeast of } \\
\text { Townsend. }\end{array}$ & 46 & 15 & 111 & 22 & $8 \pm$ & Shorter than first shock. \\
\hline Clarkston & 46 & 2 & 111 & 24 & $8 \pm$ & Do. \\
\hline $\begin{array}{l}\text { Perugin's, } 9 \text { miles southeast of } \\
\text { Townsend. }\end{array}$ & 46 & 15 & 111 & 22 & $8 \pm$ & Shorter than first shock. In two phases. \\
\hline Belgrade.... & 45 & 2 & 111 & 11 & $8 \pm$ & $\begin{array}{l}\text { At } 7.15 \mathrm{p} . \mathrm{m} \text {. Many bricks came down. One observer says it was } \\
\text { more violent than first shock; another observer who was in a mov- } \\
\text { ing automobile on a slippery road did not feel the shock. }\end{array}$ \\
\hline Willow Creek_. & 45 & 50 & 111 & 39 & $8 \pm$ & $\begin{array}{l}\text { Shorter than first shock, but trees swayed as if they would snap off. } \\
\text { House raised clear off foundation on one side and came back to } \\
\text { place. }\end{array}$ \\
\hline $\begin{array}{l}\text { Walbert's, } 9 \text { miles north-north- } \\
\text { west of Three Forks. }\end{array}$ & 46 & 2 & 111 & 38 & $7 \pm$ & Shorter than first shock. \\
\hline Radersburg & $\begin{array}{l}46 \\
45\end{array}$ & $\begin{array}{l}13 \\
48\end{array}$ & $\begin{array}{l}111 \\
111\end{array}$ & $\begin{array}{l}39 \\
12\end{array}$ & $\begin{array}{l}7 \pm \\
7 \pm\end{array}$ & $\begin{array}{l}\text { Do. } \\
\text { Do. }\end{array}$ \\
\hline Maudlow & 46 & 8 & 111 & 10 & $7 \pm$ & $\begin{array}{l}\text { Shorter than first shock. Did not shake as many goods from shelves } \\
\text { as first shock, but more bricks came down. }\end{array}$ \\
\hline 3 miles south of Manhattan & 45 & 50 & 111 & 20 & 8 & $\begin{array}{l}\text { This shock turned upper part of brick chimney one-eighth revolution } \\
\text { clockwise and threw dishes from shelves. }\end{array}$ \\
\hline $\begin{array}{l}\text { Mockel's, } 7 \text { miles south-south- } \\
\text { east of Radersburg. }\end{array}$ & 46 & 8 & 111 & 36 & $7 \pm$ & \\
\hline Helena & 46 & 36 & 112 & 0 & $5 \pm$ & $\begin{array}{l}\text { Strong vibration of several seconds at } 7.07 \mathrm{p} . \mathrm{m} \text {., but shorter and } \\
\text { weaker than first shock. }\end{array}$ \\
\hline $\begin{array}{l}\text { Whitehall } \\
\text { Jefferson Island. }\end{array}$ & 45 & $\begin{array}{l}48 \\
47\end{array}$ & 112 & $\begin{array}{r}6 \\
57\end{array}$ & $\stackrel{?}{6} \pm$ & $\begin{array}{l}\text { Shorter than first shock. } \\
\text { Do. }\end{array}$ \\
\hline Bozeman & 45 & 41 & 111 & 3 & $6 \pm$ & $\begin{array}{l}\text { Automobile moved forward and back. Flagpole swayed east and } \\
\text { west. }\end{array}$ \\
\hline $\begin{array}{l}\text { White Sulphur Springs } \\
\text { Fort Logan }\end{array}$ & $\begin{array}{l}46 \\
46\end{array}$ & $\begin{array}{l}33 \\
42\end{array}$ & $\begin{array}{l}110 \\
111\end{array}$ & $\begin{array}{l}54 \\
11\end{array}$ & $\begin{array}{l}6 \pm \\
6 \pm\end{array}$ & Wes \\
\hline $\begin{array}{l}\text { House's, } 10 \text { miles northeast of } \\
\text { Bozeman. }\end{array}$ & 45 & 50 & 110 & 53 & & Buil \\
\hline $\begin{array}{l}\text { Clyde Park } \\
\text { Norris }\end{array}$ & $\begin{array}{l}45 \\
45\end{array}$ & $\begin{array}{l}53 \\
34\end{array}$ & $\begin{array}{l}110 \\
111\end{array}$ & $\begin{array}{l}37 \\
42\end{array}$ & $?^{7 \pm}$ & $\begin{array}{l}\text { Seemed harder than first shock. } \\
\text { Half as long as first shock. }\end{array}$ \\
\hline ison. & 45 & 42 & 111 & 48 & $7+$ & $\begin{array}{l}\text { Seemed about as hard as first shock but shorter. Kitchen cabinet } \\
\text { flew open and dishes spilled. Seemed harder than first shock to one } \\
\text { observer. }\end{array}$ \\
\hline
\end{tabular}


Summary of reports of aftershock of the Montana earthquake of June 27, 1925, occurring at 7.10 p. m. mountain time-Continued

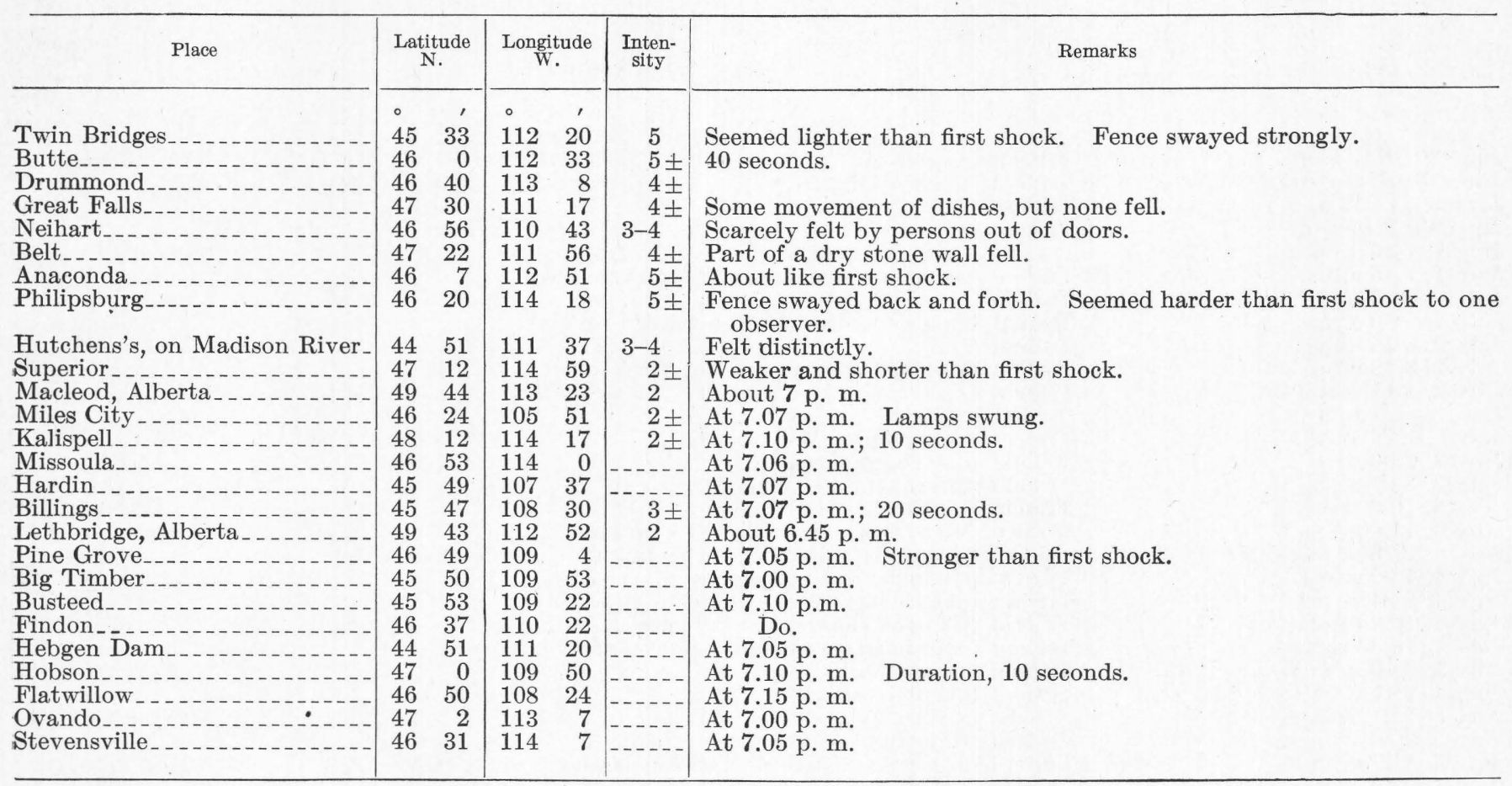

As nearly as can be determined the epicenter of the shock at 7.10 p. m. is a short distance south of the epicenter of the main shock.
Additional aftershocks up to August 13 were recorded as follows, including the 52 shocks reported by A. D. Burkett at Trident:

Aftershocks from June 27 to August 13

\begin{tabular}{|c|c|c|}
\hline Time & Places reporting & $\begin{array}{l}\text { Indicated } \\
\text { size of area } \\
\text { disturbed } \\
\text { (square miles) }\end{array}$ \\
\hline June $27,8.35$ p. m_ & Stevensville, Helena, Anaconda, B & 50,000 \\
\hline $\begin{array}{l}\text { June } 27 \text {, between } 9.20 \text { and } 9.41 \\
\text { p. m. }\end{array}$ & Conway, Philipsburg, Helena, Anac & 17,000 \\
\hline $\begin{array}{l}\text { June } 27 \text {, between } 10.25 \text { and } 10.30 \\
\text { p. m. }\end{array}$ & Anaconda, Helena, Philipsburg, & 17,000 \\
\hline $\begin{array}{l}\text { June } 27 \text {, between } 10.39 \text { and } 10.40 \\
\text { p. m. }\end{array}$ & Livingston (set light bulbs sway & 7,500 \\
\hline $\begin{array}{l}\text { June } 28 \text {, between } 1.55 \text { and } 2.00 \text { a. } \mathrm{m} \\
\text { June } 28,2.20 \text { a. } \mathrm{m}\end{array}$ & $\begin{array}{l}\text { Trident (heavy), Philipsburg } \\
\text { Trident (heavy) }\end{array}$ & 17,000 \\
\hline , 2.0 & 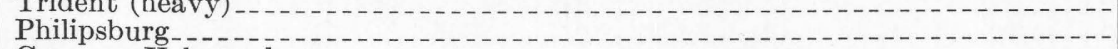 & \\
\hline June 28 , between 3.30 and 3.33 a. $\mathrm{m}_{-}$ & Conway, Hebgen dam $\ldots . . .$. & \\
\hline 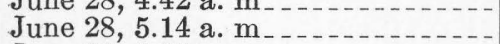 & $\begin{array}{l}\text { Trident (heavy) } \\
\text { Helena (distinct, } 2 \text { or } 3 \text { seconds) }\end{array}$ & \\
\hline 年 & Trident (moderate) & \\
\hline $\begin{array}{l}\text { June } 28,8.39 \text { a. } \mathrm{m} \\
\text { June } 28,11.00 \text { a. } \mathrm{m}\end{array}$ & Trident ${ }_{\text {Trident }}$ & \\
\hline $\begin{array}{l}\text { June } 28 \text {, between } 3.30 \text { and } 3.38 \\
\text { p. m. }\end{array}$ & Helena (light), Manhattan (heavy), Trident, Bozeman, Li & $\overline{7}, \overline{500}$ \\
\hline 10.30 p. $\mathrm{m}_{1}$ & Helena & \\
\hline No & & \\
\hline June 09 betaen 255 & ider & \\
\hline $\begin{array}{l}\text { June } 29 \text {, between } 2.25 \text { and } 2.30 \\
\text { a. m. } \\
\text { June } 29,4.10 \text { a. } \mathrm{m}\end{array}$ & $\begin{array}{l}\text { Trident (shook town from one end to the other), Helena (sharp; } 7 \text { seconds), } \\
\text { Great Falls (several seconds; dishes and pictures moved), Billings, Philipsburg. } \\
\text { Trident (small) }\end{array}$ & 50,000 \\
\hline$x$ & $\begin{array}{l}\text { Trident (sr } \\
\text { Helena }\end{array}$ & \\
\hline - & Lombard_. & \\
\hline 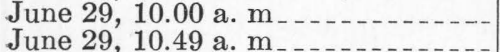 & & \\
\hline - & $\begin{array}{l}\text { Trident (moderate) }-.- \\
\text { Trident (heavy) }\end{array}$ & \\
\hline $\begin{array}{l}16 \text { p. } \mathrm{m} \\
30 \text { p. } \mathrm{m}\end{array}$ & $\begin{array}{l}\text { Trident_. } \\
\text { Bozeman }\end{array}$ & \\
\hline $\begin{array}{l}\text { June } 29 \text {, between } 11.30 \text { and } 11.35 \\
\text { p. m. }\end{array}$ & $\begin{array}{l}\text { Helena, Livingston, Philipsburg, Trident (very noticeable in kiln room), Boze- } \\
\text { man. }\end{array}$ & 30,000 \\
\hline
\end{tabular}


Aftershocks from June 27 to August 13-Continued

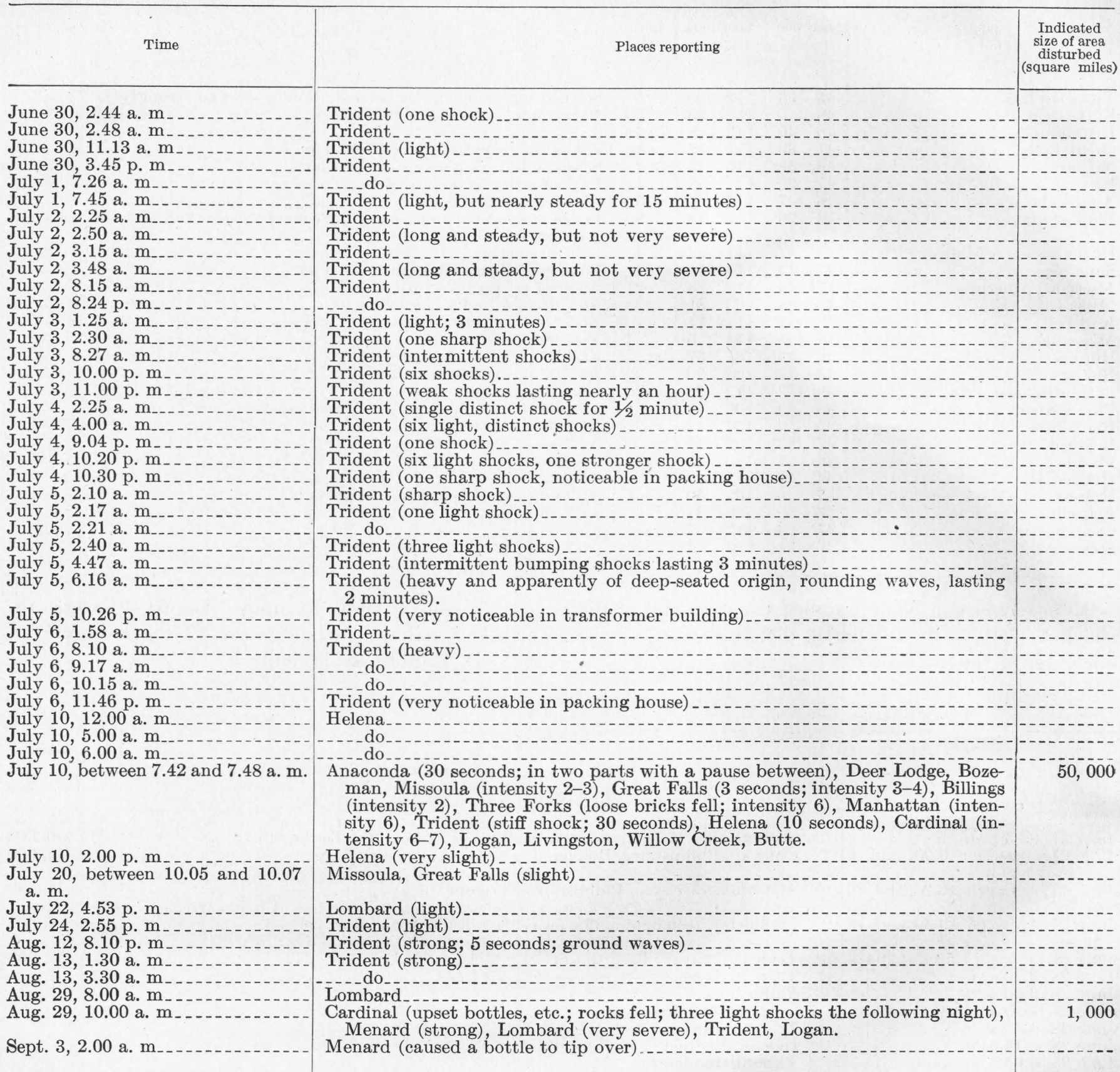

Shocks reported from Helena by the Associated Press occurred September 19 at 3.45 a. m. (sharp, short), September 30 at 2.30 a. m. (caused snow slides from roofs), and early in the day of October 6 (short, sharp). These also are doubtless to be classified as aftershocks of the earthquake of June 27, but reports of them from blaces nearer the epicenter are lacking.

PHYSIOGRAPHY AND GEOLOGY OF EPICENTRAL AREA

\section{SURFACE FEATURES}

The area within isoseismal 10 includes a lowland along Missouri River at Clarkston and parts of the hills that adjoin it on the east and north (pl. 4). The lowland, which will be referred to herein as Clarkston Valley, is a depression about 10 miles long and 5 or 6 miles across at the middle and widest part. It is bordered on the east by the moderately steep Horseshoe Hills, 1,000 to 3,000 feet high, which are in fact the extreme northern part of the Belt Mountains. At the north and south are broad spurs extending west from the Horseshoe Hills, and at the west is an unnamed range of hills of somewhat less elevation. Together the hills and ridges described form a surrounding wall that is broken at three places only, each opening being a narrow stream-cut valley or gorge. At the northeast is the gorge of Sixteenmile Creek, in which the Deer Park slide occurred. At 
the south, at Trident, is a narrow, steep-sided valley that admits Missouri River, and at the north, beginning at Lombard, is a deep, narrow, and crooked gorge, known as Horseshoe Bend, through which the river escapes.

Clarkston Valley consists of a strip of level bottom land along the river and a larger area of rather low terraces or bench lands. The terraces, which are generally known throughout this region as "benches," are remnants of stream-cut plains that were developed at higher levels and at an earlier period than the plain that now forms the valley bottom. They are due to the downcutting of streams, and it follows that most of them surmount the divides between stream courses that lead from the mountains to the river. Their fronts or edges are steep descending slopes or scarps, and their tops are smooth plains that rise gradually toward the mountains. In the gorges at Trident and Lombard and here and there along the west side of Clarkston Valley are small benches 40 or 50 feet higher than the bottom lands.

On the east side of the valley the benches occupy the greater part of an area about 3 miles wide that adjoins the mountains and extends the full length of the valley. Here the fronts or scarps of the benches are mostly 100 to 150 feet high, and their tops slope upward toward the mountain with a gradient of about 300 feet to a mile. Near the mountains this slope is increased slightly, but not enough to mask the point at which a definite and rather abrupt change to the steeper slope of the mountain takes place (pl. 4).

\section{STRATIGRAPHY}

Rocks ranging in age from pre-Cambrian to late Mesozoic (Cretaceous) form the surrounding mountains and hills and, within Clarkston Valley, probably constitute a bedrock floor beneath the Tertiary and later deposits. As shown by Peale, ${ }^{6}$ the spur that incloses the valley at the south is composed chiefly of Paleozoic limestones with some sandstone and other beds of Paleozoic and Algonkian age. The same rocks continue northward, forming the hills east and west of the valley and the spur that bounds it on the north. North of Clarkston, near the middle of the valley, a hill of the Paleozoic limestones projects through the Tertiary beds like an island in a lake, and there is a similar occurrence farther northeast on the north side of Garden Gulch. North of Lombard sandstone, shale, and limestone of Cretaceous age are folded in with the Paleozoic rocks. Excellent sections of the rocks mentioned are exposed in the gorges of Missouri River and Sixteenmile Creek, and strati-

6 Peale, A. C., U. S. Geol. Survey Geol. Atlas, Three Forks folio (No. 24), 1896. graphic details of them are given by Campbell ${ }^{7}$ and Haynes. $^{8}$

Beds of moderately hardened clay and weakly cemented sand and gravel, commonly known as Tertiary "lake beds," compose the "benches" and probably occur also beneath the alluvium of the valley bottom. They lie upon the upturned and eroded edges of the older rocks described and are in turn partly covered and concealed from view by gravel of Pleistocene and Recent age. They are correlated with the Oligocene and Miocene beds occurring a short distance to the north in. Townsend Valley ${ }^{9}$ and in the valleys of southwestern Montana generally.

\section{STRUCTURE}

The older rocks mentioned are involved in rather close folds that vary in trend from north to northeast and cause the beds in most places to be steeply inclined. The section at Trident shows an anticline that is overturned eastward and faulted. ${ }^{10}$ In the neighborhood of Deer Park several faults of apparently small extent that trend northwestward are mapped by the geologists of the Anaconda Copper Mining Co. ${ }^{11}$ Their age and displacement are not known. In the hills west of Missouri River is an overthrust fault, called the Lombard overthrust, ${ }^{12}$ that extends from a point north of Three Forks northeastward for 13 miles or more. Its trace crosses Horseshoe Bend about a mile west of Lombard. There the fault dips about $40^{\circ} \mathrm{W}$. and has brought Belt (Algonkian) rocks eastward over rocks of Cretaceous age. Beds that are stratigraphically 6,800 feet apart are in contact, and the maximum displacement is estimated at about 2 miles. The fault is younger than Lower Cretaceous (Kootenai) strata exposed near Lombard and probably older than the lower Oligocene beds described by Douglass. ${ }^{13}$

The only visible structural feature of the Tertiary beds is a persistent eastward dip of $10^{\circ}$ to $20^{\circ}$. Owing to the fact that these beds break down rather easily under weathering, good exposures are few and are generally confined to very steep slopes or newly cut ravines. Hence it is possible that some minor folds or faults were overlooked, but there seems no doubt as to the prevailing eastward dip. At only one place north of Garden Gulch and within 100 feet of the area of older rocks were the Tertiary beds observed as

7 Campbell, M. R., Guidebook of the western United States, Part A, The Northern Pacific Route: U. S. Geol. Survey Bull. 6i1, pp. 116-118, 1915.

${ }^{8}$ Haynes, W. P., The Lombard overthrust: Jour. Geology, vol. 24, pp. 269-290, 1916.

${ }^{9}$ Pardee, J. T., U. S. Geol. Survey Water-Supply Paper 539, pp. 17-34, 1925.

10 Campbell, M. R., op. cit., p. 117, fig. 26.

11 Unpublished map.

12 Haynes, W. P., op. cit.

${ }_{13}$ Douglass, Earl, Fossil Mammalia of the White River beds of Montana: Am. Philos. Soc. Trans., new ser., vol. 20, pp. 238-279, 1902. 
dipping westward. The boundary between the Tertiary and older rocks at the east edge of the valley is rather generally concealed by alluvium and deep surface mantle, but it holds a rather straight course and is not extensively deflected where it crosses gulches or ridges. Apparently, therefore, this boundary is the trace of a steeply pitching surface toward which the Tertiary beds are inclined. Such a relation is difficult to explain except as a result of faulting by which the Tertiary beds were relatively downthrown. This idea is supported by certain features of the valley itself. Clarkston Valley is a wide depression in deformed and eroded pre-Tertiary rocks. Its rim or surrounding wall is broken only by three narrow stream gorges. Such a basin could be formed in only two ways - by erosion or by structural movements. If due to erosion, it must have been an area of rocks that were softer and more easily eroded than the rocks in which the gorges were cut, which is evidently not true. Therefore there seems no alternative but to regard the valley as a relatively depressed or down-faulted area. The features of the Tertiary beds indicate that down faulting occurred along the east side of the valley during Miocene or later time, the pitch of the fault being toward the west.

Similar features are shown in Townsend Valley, a short distance to the north. There also the Tertiary beds rest in a basin depressed in the older rocks and show a persistent dip toward the east side of the valley. At the point where Sixmile Creek (which is about 4 miles north of Sixteenmile Creek) leaves the mountains the eastward-dipping Tertiary beds abut against the older rocks, ${ }^{14}$ the relation being interpreted as due to a fault with the downthrow on the side next to the valley.

\section{CAUSES OF THE EARTHQUAKE AND LOCATION OF THE FOCUS}

The size of the disturbed area, the gradual decline of intensity away from the epicenter, and other features of the Montana earthquake indicate that it was the result of fault movements rather than of volcanic action. So far as observed in the neighborhood of the epicenter no new fault displacement is manifest at the surface. This may be explained by the fact that there is a thick superficial cover of rather soft sediments (Tertiary "lake beds"), in which a slip originating in the rocks below might be distributed and lost.

Of the faults previously mapped in this region the Lombard overthrust (p. 21) is too far from the epicenter to be considered. The faults mapped by geologists of the Anaconda Co. as crossing Sixteenmile Creek near Deer Park are not far from the epicenter, but their strike differs considerably from the course of the longer axis of the isoseismal curves. They cut Paleozoic rocks, and whether they are older or newer

\footnotetext{
14 Pardee, J. T., U. S. Geol. Survey Water-Supply Paper 539, p. 32, 1925.
}

than the Tertiary beds is not known. The writer did not identify them, but owing to their location and trend he is inclined to believe that they do not contain the focus of the earthquake.

In the absence of positive evidence to the contrary it must be admitted that the earthquake may have originated along some fracture that has not yet been discovered or even suspected. All necessary conditions, however, are met by the assumption that the slip occurred in depth on the fault postulated as extending along the east side of Clarkston Valley. This fault is Miocene or younger and is probably still active.

The difference between the longer and shorter diameters of the inner isoseismal curves is from 6 to 10 miles, which presumably is of the same order of magnitude as the length of the focus or the distance along which slipping occurred. The extent of the area in which the shock was strong or destructive presumably indicates that the focus was moderately deep, perhaps several miles.

\section{PROBABILITY OF FUTURE EARTHQUAKES}

On the theory that the earthquake of June 27 with its succeeding aftershocks accomplished the relief of stresses that for some time had been accumulating a period of quiet may be expected so far as movement on the particular fault that caused the disturbance is concerned. The neighboring region, however, probably contains many other faults that are carrying unrelieved strains and may therefore become active at any time. Several of the mountain ranges of this region-Madison Range, for example-present high, steep fronts which suggest that they have been newly elevated and perhaps are still growing and therefore to be regarded as accumulating strains that will eventually result in earthquakes. Southwestern Montana is part of the Cordilleran region, which as a whole is a region in which rather severe earthquakes have occurred now and then in the past and are reasonably to be expected in the future.

In Montana prior to 1925 no destructive earthquakes have been recorded, but earlier than 50 or 60 years ago settlements here were so few and far between that strong shocks might have passed unnoticed. According to some of the pioneer residents a moderate earthquake was experienced in the Gallatin Valley in 1883 that threw dishes off shelves and awakened sleepers. In 1805 sounds that were probably of earthquake origin were noticed near the present site of Great Falls by members of the Lewis and Clark expedition. In his journal of June 18-20, 1805, Captain Clark ${ }^{15}$ records that the men of the expedition first told him of hearing the sound for which he supposed they had mistaken distant thunder. On June 19, however, while walking on the plain above the falls he himself

15 Original journals of the Lewis and Clark expedition, edited by Reuben Gold Thwaites, vol. 2, p. 176, Dodd, Mead \& Co., 1904. 
heard the noise distinctly and paused, listening for two hours, during which time it was twice repeated. He describes it as an "unaccountable rumbling" and also as resembling distant artillery fire. It seemed to come from the west, was heard at irregular intervals, and consisted of a single discharge or of several discharges in quick succession. This description tallies closely with that of sounds called brontides, ${ }^{16}$ which are regarded by authorities as partly at least of seismic origin-possibly the final representatives of a series of aftershocks.

It is probable, from the facts above set forth, together with the evidence of the recent earthquake, that the general region here considered is in a condition of moderate seismic activity and is likely to be visited by an occasional severe shock. It behooves the inhabitants, therefore, to take at least a few simple precautions toward the prevention of future damage.

${ }^{16}$ Davison, Charles, A manual of seismology, pp. 63-65, Cambridge Univ. Press, 1921.
For example, the prevailing custom of laying up veneer or face brick without ties or bonding to fasten it to the back wall should be outlawed. The use of poor or insufficient mortar is of course to be condemned under any condition. Apparently a rich Portland cement mortar will make brick walls proof against shocks as severe as the recent one, and chimneys may be prevented from falling by a few braces of strap iron. Many of the towns are built on deposits of unconsolidated stream gravel, on which a shock is likely to be more destructive than on solid rock. This condition can be overcome, however, by making the ioundations deeper and heavier than ordinarily is needed. It is evident that the wrecked schools at Three Forks and elsewhere could have been made earthquake proof when they were built, at a fraction of the cost it has taken to repair them. Apart from this there appears a more weighty consideration. When will the next earthquake come? When schools are in session or congregations assembled? 